\title{
Bir Yerel Yönetişim Aracı Olarak Adana Kent Konseyi ${ }^{1}$
}

\author{
As A Tool Of Local Governance Adana City Council
}

\section{Şükrü ARSLAN}

Kamu Yönetimi Uzmanı

sukruarslan4747@gmail.com
Makale Başvuru Tarihi / Received: 05.12.2020

Makale Kabul Tarihi / Accepted: 28.12.2020

Makale Türü / Article Type: Araştırma Makalesi

\section{ÖZET}

Bu çalışma Adana Kent Konseyi üyelerinin belediyeye katılım, gündem belirleme ve karar alma mekanizmaları içerisindeki etkinlik düzeylerinin belirlenmesi, Adana özelinde katılıma etki eden, bölgeye has özelliklerin ve işleyiş farklııklarının altında yatan sebeplerin öğrenilmesi ve elde edilen sonuçların yerel yönetişim bağlamında değerlendirilmesini amaçlamaktadır. Yapılan araştırmalarda özellikle kent konseyleri-yerel yönetişim ilişkisini ele alan akademik çalışmaların sınırlı olduğu, Adana özelinde ise daha önce böyle bir çalışmanın yapılmadığı görülmüştür. Bundan dolayı bu çalışmanın mevcut durumun kısıtııı̆ına doğrudan işaret etmesi ve alandaki boşluğun doldurulmasına yardımcı olunması bakımından önem taşımaktadır. Henüz bakir sayılan bu alanın akademik olarak zenginleştirme çabası içinde olunması, yapılan saha çalışması ile alanın bilgisinin ölçülmesi ve daha öncesinde yapılan genel kuramsal ölçüler etrafında mukayese etme fırsatının yakalanması açısından sahada çalışmak isteyen araştırmacılara katkı sağlaması beklenmektedir. Adana Kent Konseyini yerel yönetişim bağlamında değerlendirebilmek için konsey üyelerine anket uygulanmıştır. Anket uygulaması sonucunda elde edilen veriler SPSS 20,0 Forwindows hazır paket programına yüklenmiş ve araştırma amaçları doğrultusunda istatistiksel analizlere tabi tutulmuştur. Araştırma sonucu elde edilen veriler, her soruya ve konu alanına göre frekans ve yüzde şeklinde gösterilmiş ve sonuçlar güvenirliliği test edilmiş veriler ışığında değerlendirilmiştir.

Anahtar Kelimeler: Yönetişim, Yerel Yönetişim, Kent Konseyleri, Adana

\section{ABSTRACT}

This study aims to evaluate the participation of Adana City Council members in the municipality, their level of activity in agenda-setting and decision-making mechanisms, to learn the characteristics of the region that affect participation and the reasons underlying the operational differences in Adana, and to evaluate the results in the context of local governance. It is observed that academic studies on the relationship between city councils and local governance are limited, and no such study has been conducted before in Adana. Therefore, this study is important in terms of pointing directly to the limitation of the current situation and helping to fill the gap in the field. It is expected to contribute to researchers who want to work in the field in order to be in an effort to enrich academically this field, which is considered to be immature, to measure the knowledge of the field with the field work and to have the opportunity to compare it around the general theoretical criteria that were previously made. In order to evaluate Adana City Council in the context of local governance, a questionnaire was applied to the members of the council. The data obtained as a result of the survey application were analyzed with the SPSS 20 package program. The data obtained as a result of the research were shown as frequency and percentage, and the results were evaluated in the light of the reliability tested data.

Keywords: Governance, Local Governance, City Councils, Adana

\footnotetext{
${ }^{1}$ Bu makale "Türkiye'de Yerel Yönetişim ve Kent Konseyleri: Adana Örneği” adlı yüksek lisans tezinden uyarlanmıştır.
} 


\section{GiRiş}

21. yüzyılın getirdiği değişimler ve Türkiye'nin $A B$ üyelik süreci kamu yönetiminde değişimin gerekliliğini ortaya koymuştur. Türk kamu yönetiminde reform ihtiyacı önemli oranda sistemin kendi iç sorunlarından kaynaklansa da, diğer dış etmenlerin tesirinin yanında, özellikle Avrupa Birliği müzakere sürecinin idari yapıyı birlik ölçütlerine göre yeniden düzenlenmesini zorunlu kılması, reformu tetikleyen nedenlerin başında yer almıştır. Büyük bölümünün yerel yönetimlerle ilgili olduğu Avrupa Birliği mevzuatı, üyelik başvurusunda bulunan ülkelerin bu kapsamda değişiklik yapmasını şart koşması ile Türkiye'de 2000'li yıllarda, yerel yönetimlerin güçlendirmesi amacıyla hesap verebilirliğin artırılması, merkeziyetçiliğin azaltılması, hizmetlerin vatandaşa ulaştırılması, vatandaşın yönetime katılımının artırılması için reformlar gerçekleştirilmesi gerektiği ön koşulmuştur. Avrupa Yerel Yönetimler Özerklik şartında ifade edilen merkezi idarenin ilgili görevlerinin belirlenmesi ve diğer tüm görevlerin yerel yönetimlere bırakılması gerektiği; ortaya konan işlerle alakalı olarak vatandaşa sahiplik duygusunun verilmesi, vatandaş katılımının artırılması ve yerel sorunların daha iyi belirlenmesi için kent konseylerinin oluşturulması gerektiği yer almıştır.

Bunun üzerine kent konseyleri 2005 yılında Türkiye'deki Yerel Gündem 21 eylem planının 3. aşamasıyla beraber Türk hukuk sistemine girmiş ve 2005 yılında tüm belediyelerde kurulmaları zorunlu hale getirilmiştir. Bu kuruluşun çalışmaları Yerel Gündem 21 ortağı olan kentlerde kuruluş çalışmalarındaki tecrübelerden faydalanılarak hızlı bir şekilde program ortağı olmayan kentlere de yayılmıştır. Belediye kanununda yer alan 76 . maddeye dayanılarak çıkarılan kent konseyi yönetmeliği ile belediyelerde kent konseylerinin kurulmasında izlenecek yol ve kent konseylerinin görevleri daha net olarak tanımlanmıştır. $\mathrm{Bu}$ hızlı kuruluş çalışmaları, beraberinde yönetmelikteki sorunların hissedilir olmasını sağlamış ve 2009 yılında kent konseyi yönetmeliğinde değişikliğe gidilmiştir. Fakat kanun ve yönetmelik kent konseylerinin kuruluş ve işleyişine istenilen düzeyde cevap verememiştir. Bu nedenle kuruluşunu örnek şekilde tamamlayan belediyeler diğer belediyeler tarafından örnek model olarak alınmış ve yeni kurulan kent konseyleri bu çerçevede gelişim göstermiştir.

Adana Kent Konseyi, Adana Büyükşehir Belediyesi'nde Yerel Gündem 21'in oluşturulmasıyla başlamıştır. Adana Büyükşehir Belediyesinin 2000 yılı haziran ayında, "Türkiye'de Yerel Gündem 21'lerin Geliştirilmesi" projesine katılım kararı almasıyla beraber belediye proje ortakları arasına girmiş ve Büyükşehir Belediyesi bünyesinde Yerel Gündem 21 Kurulu oluşturulmuştur. Bu kurul öncülüğünde başlatılan çalışmalara 41 sivil toplum kuruluşu ve meslek örgütünün katılımı ile Adana Kent Konseyi kurucular kurulu meydana getirilmiş; ardından, kurucular kurulunun yürüttüğü hazırlık çalışmaları kapsamında, rehber bilgiler, kent konseyi tüzüğü ve bağlı yönetmelikleri çıkararak 17 Mayıs 2001'de tarihinde ilk olağan genel kurul toplantısını gerçekleştirmiştir.

\section{YÖNETIŞ̧iM VE KENT KONSEYLERi}

\subsection{Yönetişimin Tarihsel Gelişimi}

Çağdaş bir yönetim yaklaşımı olarak yönetişim, kamu ve özel sektör ile sivil toplum kuruluşlarından aktörlerin bir araya gelerek ortak amaçlar için pazarlık yapmasını öngördüğü ve bu anlamda tarafların birbirlerinin değerlerini ve önceliklerinin benimsemeseler bile anlamları beklendiğini vurgulayan bir yaklaşımdır. Bu yaklaşımda, merkezi yönetimin yetki ve otoritesini sivil toplum örgütleri ile paylaştığı, devlet otoritesine dayanmayan, çoğulcu 
yönetim biçimlerinin ve aktörlerinin etkileşimiyle katılımcı bir yönetim şekli öngördüğü, ortaya çıkan yeni yönetim süreçlerini açıklamaya çalışan ve toplumun daha etkin ve demokratik olarak yönetilmesine ilişkin öneriler sunan kuramsal bir çerçeve olduğu savunulur (Aydın, 2016: 210).

Yönetişim, ilk kez 1989 Dünya Bankası Raporuyla literatüre girmiştir. Söz konusu raporda Güney Sahra Bölge'sinde yer alan devletlerin yaşadıkları yönetsel sorunlar irdelenerek ekonomide yaşanan bunalımları devletin tetiklediği kanısına varılmış, yönetişim kavramı bir ülkenin işlerinde siyasal iktidarın rolü şeklinde değerlendirilmiştir (Memduh ve Yılmaz, 2010: 13 ). Dünya Bankası raporunun Afrika'nın yönetim krizinin "yönetişim" ile aşılacağı yaklaşımının başarılı bulunması ile "yönetişim" bilimsel yaklaşım çerçevesine alınarak literatüre sokulmuştur.

1990'ların sonuna gelindiğinde Avrupa Birliği de aynı kavramı kendi iç uygulamalarında kullanma gereğini duyup, Avrupa Yönetişimi Beyaz Kitabı adlı belgeyle bir çalışma başlatmıştır (DPT, 2007: 2). Yönetişimin kısa bir zaman diliminde popüler hale gelmesi ve değişik kesimlerce kullanılmasını Gündoğan (2010: 15) şöyle yorumlamıştır: Kavramın dar bir çerçevede kesin tanımlamaya elverişli olmayan ancak cezbeden yapısı nedeniyle, kamu yönetiminde yeniden yapılanma tartışmalarında yer alan kesimler, taraf ya da karşı olmalarına bakılmaksızın, ona kayıtsız kalamamıştır. Her kesim kavramın bir tarafını öne çıkarıp, tartışmaları belli bir istikamette yönlendirmek amacıyla kullanmaya çalışmıştır. Bu da kavramın yaygın birçok anlamının, tanımının ve kullanım alanının ortaya çıkmasına yol açmıştır.

\subsection{Kent Konseyleri}

Kent konseylerinin kökenini Gündem 21, Yerel Gündem 21 ve Avrupa Kentsel Şartı oluşturmaktadır (Sağır, 2003: 29). Gündem 21 çerçevesinde belirlenen hedeflerin gerçekleştirilmesinde yerel yönetimlerin katılımı ve işbirliğinin, belirleyici bir etken olacağı ifade edilmiştir. Bu kapsamda Türkiye'de de 1997 yılında "Türkiye'de Yerel Gündem 21'lerin Teşviki ve Geliştirilmesi Projesi" Birleşmiş Milletler Kalkınma Programı (UNDP) Türkiye Daimi Temsilciliği ve Uluslararası Yerel Yönetimler Birliği, Doğu Akdeniz ve Ortadoğu Bölge Teşkilatının (IULA-EMME) katkılarıyla başlamıştır.

Kent Konseylerinin ana amacı, yerel düzeyde katılım ve demokrasinin hayata geçirilmesini, sivil toplumun karar mekanizmalarında aktif rol alarak yerel faaliyetlerin belirleyicilerinden olmalarını ve yerel yönetişimi etkin hale getirmeyi amaçlamaktadır. Ayrıca kent konseyleri yerel kalkınmanın gerçekleştirilmesinde merkezi yönetim, yerel yönetim, sivil toplum kuruluşları ve yerel halk arasında kurulacak işbirliği çerçevesinde yerel yönetişime dayalı bir kalkınma politikası oluşturmayı da hedeflemektedir ( Eroğlu, 2010: 44-45)

\subsection{Türkiye'de Kent Konseylerinin Oluşum Süreci ve Gelişimi}

Türkiye'de kent konseyleri, bir yasal zorunluluk olarak yeni olmakla birlikte aslında uygulamada yeni olmadıkları, daha önce Yerel Gündem 21 adı altında veya bu adın altında olmasa da kent meclisi veya benzeri yapılanmalar yoluyla ama ihtiyari olarak uygulanmakta oldukları, sonrasında gerekli mevzuat düzenlemeliyle yasal zorunluluk haline getirildikleri söylenebilir ( Bülbül, 2009: 71). Kent Konseylerinin Türkiye'deki gelişimi, kent konseylerinin teorik alt yapısını hazırlayan ve ilk uygulamaların ortaya çıkışını sağlayan Yerel Gündem 21 ile Türkiye'nin tanışması ve kent konseylerinin yasal bir zemine kavuşturulması gibi iki önemli dönüm noktası vardır. 
Birleşmiş Milletler Kalkınma Programı altında sürdürülen, Türkiye'de Yerel gündem 21 uygulaması ilk defa 1997 yılının sonlarında "Türkiye'de Yerel Gündem 21'lerin Teşviki ve Geliştirilmesi" Projesi ile başlamıştır (06.03.1998, Resmi Gazete). Proje olarak başlayan süreç zamanla Yerel Gündem 21 programına dönüştürülmüştür.

\subsubsection{Belediye Kanunu ve İlgili Yönetmelikte Kent Konseyleri}

5393 sayılı kanun yerel yönetimler reformu kapsamında hazırlanmış bir kanundur. Kanun, vatandaş odaklılığına, siyasal ve yönetim süreçlerine vatandaşın dahil olunmasına vurgu yapar ve kent konseylerinin önemine dikkat çeker. Ayrıca, yerelde sunulan kamu hizmetlerinden yararlananların memnuniyetini artırmak, yapılan hizmetlerin hukuka uygun olmasını, etkili ve verimli olmak için yerelin isteklerini temel alan bir anlayışın sergilenmesi gerektiği belirtilmiştir. Buna gerekçe olarak da hizmetlerin etkililiğinin vatandaşın katılımıyla doğru orantılı olacağı düşüncesine bağlanmaktadır. Bu düşünce doğrultusunda kanunun 9. maddesinde muhtarlar üzerinden mahalle ölçeğinde katılımın artırılmasına yer verilmiştir.

Kanunun 13. maddesinde hemşehrilik vurgusu yapılmış ve kentlilerin belediye hizmetlerine katılımlarını ve hizmetlerden haberdar olmalarını bir hak olarak tanımıştır. Kanunun 41. maddesinde yerel birimlerin ortak hedefler doğrultusunda bir araya gelmelerine, kendi aralarında işbirliğini artırmak için katılımcı bir eksen etrafında ortaklık kurmalarına imkân tanırken, 77. maddede yerel yönetimlerde gönüllü katılıma ve yerel hizmetlerin sunumunda gönüllü katılımın artırılması için programların uygulanması gerektiğine vurgu yapılmıştır. Yerel yönetişimin hayata geçirilmesinde ve devamlılığının sağlanmasında halk katılımı ve gönüllülük önem taşımaktadır.

5393 sayılı kanunda kent konseylerine yönelik en dikkat çekici maddesi 76. maddedir. Burada kent konseyleri üzerinden yerel yönetişime ve katılımcılığa dikkat çekmiştir. Bu madde kent konseylerine dört önemli görev yüklemiştir. Birincisi, yaşanılabilir bir kent için kent sakinlerinin kentin hak ve hukukunu koruması gerektiğini; ikincisi, sosyal yardımlaşma ve dayanışmanın sağlanması konusunda kent konseylerinin görev alması gerektiğini, üçüncü olarak, hemşehri bilincinin geliştirilmesini ve son olarak da yerelde hesap verilmesini, hesap sorulmasını, katılımın ve yönetişimin gerçekleştirilmesi gerektiğini misyon olarak kent konseylerine yüklemiştir (Özcan ve Yurttaş, 2010: 168-169). Aynı madde devamında kent konseyi çalışma usul ve esaslarının yönetmelikle belirleneceğini ifade etmiştir.

\section{BIR YEREL YÖNETiŞiM ARACI OLARAK ADANA KENT KONSEYI}

\subsection{Adana Kent Konseyi}

Adana Kent Konseyi, Adana Büyükşehir Belediyesi'nde Yerel Gündem 21'in oluşturulmasıyla başlamıştır (Adnan Kent Konseyi Faaliyet Raporu: 2014-2015). Adana Büyükşehir Belediyesinin 2000 yılı haziran ayında, "Türkiye'de Yerel Gündem 21'lerin Geliştirilmesi" projesine katılım kararı almasıyla beraber belediye proje ortakları arasına girmiş ve Büyükşehir Belediyesi bünyesinde Yerel Gündem 21 Kurulu oluşturulmuştur. Bu kurul öncülüğünde başlatılan çalışmalarla 41 sivil toplum kuruluşu ve meslek örgütünün katılımı ile Adana Kent Konseyi Kurucular Kurulu meydana getirilmiş; ardından, kurucular kurulunun yürüttüğü hazırlık çalışmaları kapsamında, rehber bilgiler, Kent Konseyi Tüzüğü ve bağlı yönetmelikleri çıkarılarak kitaplaştırılmıştır. Adana Kent Konseyi'nin ilk olağan genel kurul toplantısı, 17 Mayıs 2001'de yapılmıştır. Kent Konseyi Koordinasyon Kurulu kurumsal kotalar doğrultusunda 57 üyenin katılımıyla ilk toplantısını 02 Ekim 2001 tarihinde gerçekleştiren konsey, yürütme kurulunu seçim yoluyla belirlemiştir. 
Birinci olağan genel kurulun ardından, Adana Kent Konseyi 2. olağan genel kurul toplantısını, 06 Haziran 2002'de gerçekleştirmiş ve genel kurul toplantısında oy birliği ile kabul edilen 22 maddelik "Adana Kentli Hakları Bildirgesi", alınan kararla günümüze kadar taşınmıştır (01.05.2016, www.adanakentkonseyi.org.tr).

\section{ADANA KENT KONSEYI ÜZERINDE YAPILAN ALAN ARŞTIRMASINDAN ELDE EDILEN VERILERIN ANALIZi}

\subsection{Araştırmanın Amacı}

Bu araştırmanın amacı Adana Kent Konseyi'nin yerel yönetişim bağlamında işlevsel olup olmadığının belirlenmesidir. Bu anlamda bir yandan kent konseyinin kentin yönetilmesine katılım ve duyarlılı̆ı ele alınırken diğer yandan ise karar alma sürecine kent konseyinin ne ölçüde katıldığı ve demokratik katılımcı mekanizmalarının ne şekilde işletildiğinin irdelenmesidir.

\subsection{Araştırmanın Yöntemi}

Adana Kent Konseyi'nin yerel yönetişim bağlamında değerlendirmek amacıyla alan araştırılması yapılmasına ve konsey üyelerinin görüşlerinin belirlenmesi amacıyla da anket yönteminin uygulanmasına karar verilmiştir. Anket iki bölümden oluşmaktadır. Birinci bölümde üyelerin demografik yapılarına yönelik sorular, ikinci bölümde ise üyelerinin görüşlerinin belirlenmesine yönelik sorular yer almaktadır. Demografik yapıya yönelik sorular dışında, yerel yönetişimin ilkeleri ve özellikleri çerçevesinde ikisi açık uçlu olmak üzere toplam 35 soru hazırlanmıştır.

Anket sonucunda elde edilen veriler SPSS 20,0 Forwindows hazır paket programına yüklenerek istatistiksel analizlere tabi tutulmuştur. Yapılan güvenirlik analizleri sonucunda Alpha Katsayısı 0,762 olarak ölçülmüş ve bu analiz sonuçlarının güvenirlilik ve geçerlilik analizi açısından soruların anlaşılır olduğunu ve değişkenlerinin de bu ölçekleri ölçebileceğini göstermiştir.

\subsection{Araştırmanın Analizi}

Araştırma anket formunda demografik sorulardan sonraki sorular Türkiye'de yerel yönetişim ve kent konseyleri düzeyinde toplam 25 ifadeden oluşmaktadır. 1- Evet, 2-Hayır, 3Kısmen ve 4-Fikrim yok seçeneklerinden oluşan 4'lü Likert tipi ölçektir. Araştırma kapsamında elde edilmiş anket uygulaması sonucunda veriler SPSS 20,0 Forwindows hazır paket programına kodlanarak yüklenmiş ve araştırma amaçları doğrultusunda istatistiksel analizlere tabi tutulmuştur. Araştırma sonucu elde edilen veriler, her soruya ve konu alanına göre frekans ve yüzde şeklinde gösterilmiştir.

Araştırmadaki sorular üzerinde yapılan güvenirlilik testi aşağıdaki tabloda verilmiş olup bu analiz sonuçlarının üzerinde testlerin uygulanması son derece güvenilir sonuçlar vereceği şeklindedir.

Tablo 4.1. KMO ve Bartlett Testi

\begin{tabular}{|c|c|c|}
\hline \multicolumn{3}{|c|}{ KMO and Bartlett's Test } \\
\hline $\begin{array}{r}\text { Kaiser-Meyer-Olk } \\
A C\end{array}$ & $\begin{array}{l}\text { asure of Sampling } \\
\text { cy. }\end{array}$ & ,762 \\
\hline Bartlett's Test of & Approx. Chi-Square & 2404,400 \\
\hline Sphericity & $\mathrm{df}$ & 102 \\
\hline
\end{tabular}


KMO değeri (.762); bu örnekteki 102 kişilik örneklem büyüklüğünün yeterli olduğunu ve Bartlett's testi sonuçları da $(p<.01)$; verilerin normal dağılıma sahip olduğunu göstermektedir. Bu analiz ışığında 4'lü Likert ölçekli araştırma soruları üzerinde çeşitli analiz yapılabilirliği sağlanmıştır.

Tablo 4.2. Girilen/Kaldırılan Değişkenler (b)

\begin{tabular}{cccc}
\hline $\begin{array}{c}\text { Mod } \\
\text { el }\end{array}$ & $\begin{array}{c}\text { Girilen } \\
\text { Değişkenler }\end{array}$ & $\begin{array}{c}\text { Kaldırılan } \\
\text { Değişkenler }\end{array}$ & Metot \\
\hline 1 & Yerel & & \\
& Yönetişim, & & \\
& Kent Konseyi & & Başlama \\
& Kararları, &. & \\
& Üyelerin Kent & & \\
& Konseyine & & \\
& Katılımı(a) & & \\
&
\end{tabular}

a) İstenen Tüm Değişkenler Girildi

b) Bağımlı Değişken: Kent Konseyi

Tablo 4.3. Model Özeti (b)

\begin{tabular}{cccccc}
\hline $\begin{array}{c}\text { Mod } \\
\text { el }\end{array}$ & $R$ & R Square & $\begin{array}{c}\text { Adjusted } \\
\text { R Square }\end{array}$ & $\begin{array}{c}\text { Std. Error } \\
\text { of the } \\
\text { Estimate }\end{array}$ & $\begin{array}{c}\text { Durbin- } \\
\text { Watson }\end{array}$ \\
\hline 1 & $.823^{(\mathrm{a})}$ & .734 & .668 & .49765 & 1.485 \\
\hline
\end{tabular}

a) Belirleyiciler: ( Sabit), Kent Konseyi Kararları, Üyelerin Kent Konseyine Katılımı

b) Bağımlı Değişken: Yerel Yönetişim

\subsection{Araştırmanın Modeli}

Bu araştırmada, çalışmanın bir bölümü literatür taramasına dayanmaktadır. Ayrıca tümdengelim yöntemi ile yönetişim ve yerel yönetişim kavramları detaylı incelenmiş, kent konseylerinin bu doğrultudaki fonksiyonu açıklayıcı olarak analiz edilmiştir. Çalışmanın uygulama kısmında ise, tümevarım yöntemi ile oluşturulan anket aracılığıyla toplanan veriler analiz edilmiştir. Bu analizler sonucunda, Adana Kent Konseyi yerel yönetişim bağlamında işlevselliği ortaya konulmuştur.

Çalışmanın uygulama kısmında araştırmaya konu olan Adana Kent Konseyi, yerel yönetişim bağlamında başarılı bir şekilde uygulanıyor mu? Aksaklıkları var mı? Varsa, bu aksaklıklar nereden kaynaklanıyor? Bunun tespitini yapmak için bağımlı ve bağımsız değişkenlerden oluşan bir model oluşturulmuştur. Modelin bağımlı değişkeni Adana Kent Konseyi, bağımsız değişkenleri ise kent konseyi kararları üzerinde etkili olan, siyasi partiler, odalar ve sendikalar olarak belirlenmiştir. Bu yapılar ve bunların kendi aralarındaki ilişkileri regresyon testine tabi tutulmuş ve model test edilmiştir. 


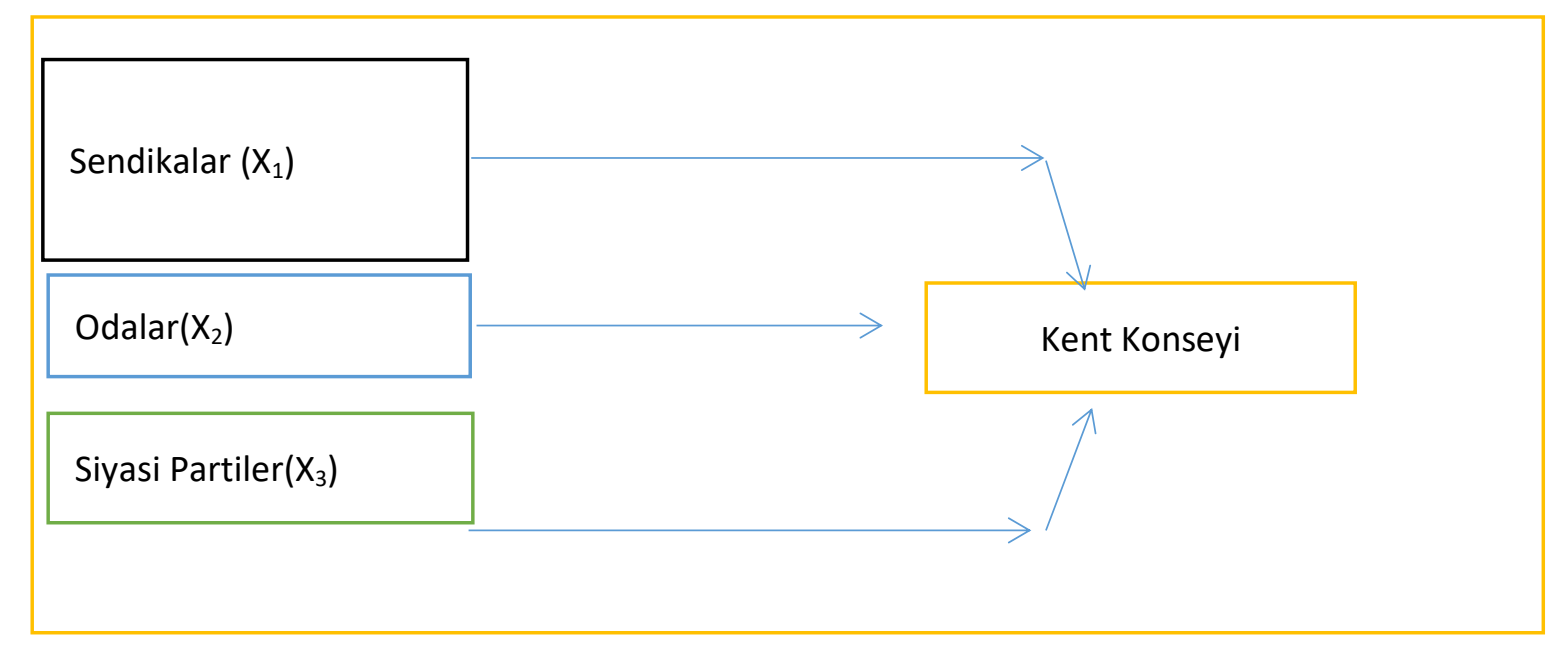

\subsection{Araştırmanın Hipotezleri}

Araştırmaya konu olan kent konseyi kararlarının Adana ilinde yerel yönetişim bağlamında önemi vurgulanabiliyor mu? Sorunlar çözülüyor mu? Çözülemiyorsa kent konsey yapısının hangi ayağında ve nereden kaynaklanıyor? Bunun tespitini yapmak için bağımsız değişkenler; sendikalar, odalar ve siyasi partiler şeklinde sıralanırken, bağımlı tek değişkenimiz kent konseyinin kararları şeklinde bir model oluşturularak bu modelde değişkenler arasındaki hipotezler ise $\mathrm{H}_{1}, \mathrm{H}_{2}$ ve $\mathrm{H}_{3}$ şeklinde aşağıda oluşturulmuştur.

$\mathrm{H}_{1}$ : Kent Konseyi kararları üzerinde Sendikalar etkilidir.

$\mathrm{H}_{2}$ : Kent Konseyi kararları üzerinde Odalar etkilidir.

$\mathrm{H}_{3}$ : Kent Konseyi kararları üzerinde Siyasi Partiler etkilidir.

Yukardaki modelin açıklayıcı denklemi ise aşağıdaki yöntemlerle elde edilir.

Eğer Model $\mathrm{n}$ tane bağımsız değişken için yazılırsa tahmin edilen çoklu doğrusal modeli;

$\widehat{Y_{l}}=a+b 1 X 1+b 2 X 2+b 3 X 3+\cdots \ldots+b n X n$

Üç tane bağımsız değişken için yazılacak tahmini model ise;

$\widehat{Y}_{l}=a+b 1 X 1+b 2 X 2+b 3 X 3+\varepsilon$ şeklindedir.

Burada;

$\widehat{Y_{l}}=$ Kent Konseyi

$b 1 X 1=$ Sendikalar

$b 2 \times 2=$ odalar

$b 3 X 3=$ Siyasi Partiler 
Tablo 4.4. Girilen/Kaldırılan Değişkenler(b)

\begin{tabular}{clcc}
$\begin{array}{c}\text { Mod } \\
\text { el }\end{array}$ & $\begin{array}{c}\text { Girilen } \\
\text { Değişkenler }\end{array}$ & $\begin{array}{c}\text { Kaldırılan } \\
\text { Değişkenler }\end{array}$ & Metod \\
\hline & $\begin{array}{l}\text { Siyasi Partiler, } \\
\text { Sendikalar, } \\
\text { Odalar(a) }\end{array}$ &. & Başlama \\
& & &
\end{tabular}

a) İstenen Tüm Değişkenler Girildi

b) Bağımlı Değişken: Kent Konseyi

Tablo 4.5. Model Özeti(b)

\begin{tabular}{cccccc}
\hline $\begin{array}{c}\text { Mod } \\
\text { el }\end{array}$ & $R$ & R Kare & $\begin{array}{c}\text { Düzeltilm } \\
\text { iş R kare }\end{array}$ & $\begin{array}{c}\text { Tahmini } \\
\text { Hata }\end{array}$ & $\begin{array}{c}\text { Durbin- } \\
\text { Watson }\end{array}$ \\
\hline 1 & $.823^{\text {(a) }}$ & .734 & .668 & .49765 & 1.485 \\
\hline
\end{tabular}

a) Belirleyiciler: ( Sabit), Siyasi Partiler, Sendikalar, Odalar

b) Bağımlı Değişken: Kent Konseyi

Tablodaki çıktı, model özeti başlıklı tablo incelendiğinde, bağımsız değişkendeki gruplar, siyasi partiler, sendikalar, odalar toplam değişimin \%73'ü bağımlı değişken olan kent konseyi alt grubu tarafından açıklandığını veya bu değişkenlerin, değişkenliğini \%73'ünü açıkladığını söylemektedir. Bununla birlikte varyans analizini sonucunda kurulan çoklu regresyon modelinin genel olarak anlamlı olduğu görülmektedir $(p<0.05)$.

Tablo 4.6. ANOVA ${ }^{(b)}$

\begin{tabular}{|c|c|c|c|c|c|c|}
\hline $\begin{array}{c}\text { Mod } \\
\text { el }\end{array}$ & & $\begin{array}{l}\text { Karelerin } \\
\text { Toplamı }\end{array}$ & $d f$ & $\begin{array}{c}\text { Kare } \\
\text { Ortalama }\end{array}$ & $\mathrm{F}$ & Sig. \\
\hline \multirow{3}{*}{1} & Gerileme & 9256.37 & 3 & 112.092 & 208.828 & $.000^{(a)}$ \\
\hline & $\begin{array}{l}\text { Artan- } \\
\text { Kalan }\end{array}$ & 826.27 & 99 & 12.248 & & \\
\hline & Toplam & 3082.6 & 102 & & & \\
\hline
\end{tabular}

a) Belirleyiciler: ( Sabit), Siyasi Partiler, Sendikalar, Odalar

b) Bağımlı Değişken: Kent Konseyi

ANOVA tablosuna bakıldığında $F$ istatistik değerinin 208.82 ve buna karşılık gözlenen anlamlılık düzeyinin de 000 olduğu görülmektedir $(p<0.01)$. Bu durum kurulan çoklu regresyon modelinin genel olarak anlamlı olduğunu belirtmektedir. Tahmin edilen çoklu regresyon modeli "Kat Sayılar ${ }^{(a) "}$ başlıklı tabloda yer almaktadır. Tabloda yer alan değerler ise aşağıdaki gibi düzenlenmektedir. 
Tablo 4.7. Kat Sayılar ${ }^{(a)}$

\begin{tabular}{|c|c|c|c|c|c|c|}
\hline & \multirow[t]{2}{*}{ Model } & \multicolumn{2}{|c|}{$\begin{array}{c}\text { Standartlaştırılma } \\
\text { mış } \\
\text { Kat Sayılar }\end{array}$} & \multirow{2}{*}{$\begin{array}{c}\text { Standartlaştırıl } \\
\text { mış Kat Sayılar } \\
\text { Beta }\end{array}$} & \multirow[t]{2}{*}{$\mathrm{t}$} & \multirow[t]{2}{*}{ Sig. } \\
\hline & & B & Std. Hata & & & \\
\hline \multirow[t]{4}{*}{1} & (Sabit) & 2.294 & .138 & & 2.234 & .000 \\
\hline & Siyasi Partiler & .121 & .037 & .162 & 1.294 & .001 \\
\hline & Sendikalar & .146 & .039 & .182 & 1.718 & .000 \\
\hline & Odalar & .243 & .097 & .322 & 3.574 & .000 \\
\hline
\end{tabular}

a) Bağımlı Değişken: Kent Konseyi

Araştırma modelimizdeki bağımlı değişkenler ile bağımsız değişkenler arasındaki ilişkiyi gösteren matematiksel modelimiz ise;

Kent konseyi $=2.294+(0.121)$ Siyasi Partiler $+(0.146)$ Sendikalar $+(0.243)$ Odalar

Sendikalar $=\mathrm{X}_{1}$

Odalar $=\mathrm{X}_{2}$

Siyasi partiler $=\mathrm{X}_{3}$

Kent konseyi $=Y$

Kent konseyinin alt boyutları (sendikalar, siyasi partiler ve odalar)

$Y=2.294+0.21 X_{1}+0.41 X_{2}+0.243 X_{3}$ şeklindedir.

Bağımsız değişkenlerden sendikalar, odalar, siyasi parti gibi değişken olan kent konseyi kararları üzerinde anlamlı düzeyde etkisinin olduğu görülmektedir. Kent konseyi kararlarının alt boyutu model üzerinde incelendiğinde; sendikalar, odalar ve siyasi partiler üzerinde en yüksek etkiye sahip olduğu korelasyon (Correlations) katsayısı ile ortaya konmuştur. Yine Modeldeki kent konseyi alt boyutlarından olan odalar, siyasi partiler üzerinde en yüksek etkiye sahip olduğu korelasyon (Correlations) katsayısı ile ortaya konmuştur.

Tablo 4.8. Deneklerin Cinsiyet Durumuna Göre Üyelerin Kayıtlı Olduğu Sivil Toplum Kuruluşları

\begin{tabular}{lccccc}
\hline & Kadın & Erkek & $\bar{x}$ & $\mathrm{P}$ & $\mathrm{F}$ \\
\hline Sendikalar & 5 & 19 & 2,651 & 0,0511 & 1,154 \\
\hline Odalar & 3 & 22 & 2,782 & 0,0632 & 1,453 \\
\hline Siyasi Partiler & 12 & 41 & 2,042 & 0,0747 & 1,351 \\
\hline Toplam & 20 & 82 & & &
\end{tabular}

Katılımcıların, kent konseyi kararlar üzerinde (sendikalar, odalar ve siyasi partiler) cinsiyete göre bir farklılık olup olmadığını belirlemeye yönelik olarak ANOVA testine tabi tutulmuş ve sonuç olarak da anlamlı bir fark görülmemiştir ( $p>0.05)$. 
Tablo 4.9. Yaş Durumuna Göre Üyelerin Kayıtlı Olunan Sivil Toplum Kuruluşları

\begin{tabular}{lccccccc}
\hline & $18-25$ & $26-31$ & $32-37$ & $46+$ & $\bar{X}$ & $\mathrm{P}$ & $\mathrm{F}$ \\
\hline Sendikalar & 2 & 3 & 5 & 23 & 2,182 & 0,0433 & 1,455 \\
\hline Odalar & 1 & 5 & 6 & 16 & 2,756 & 0,0484 & 1,731 \\
\hline $\begin{array}{l}\text { Siyasi } \\
\text { Partiler }\end{array}$ & 5 & 6 & 9 & 21 & 2,035 & 0,0021 & 1,632 \\
\hline Toplam & 8 & 14 & 20 & 60 & & & \\
\hline
\end{tabular}

Katılımcıların, yaş gruplarının, kent konseyi alt boyutları açısından farklılık gösterip göstermediğine tek yönlü varyans analizi (One Way ANOVA) ile bakılmıştır. Analiz sonucunda gruplar arasında sendikalar alt boyutu açısından anlamlı fark bulunmazken, siyasi parti (F:1.63, $\mathrm{P}<0.05)$ ve odalar olarak (F:1.632, $\mathrm{P}<0.01)$ alt boyutlar açısından belirlenen farkın hangi gruplar arasında olduğu tespit etmek için yapılan Tukey testinde 18-25 yaş grubundaki çalışanların 46 ve üzeri yaş grubu üyelerine göre karar vermede daha etkili olduğu görülmüştür. Sendikalar ise 32-37 yaş grubunun 18-26 yaş grubuna göre kararları daha yüksek düzeyde etkilediği görülmüştür.

Tablo 4.10. Eğitim Durumlarına Göre Deneklerin Kayıtlı Olduğu Sivil Toplum Kuruluşları

\begin{tabular}{|c|c|c|c|c|c|c|c|}
\hline & Lise & Önlisans & Lisans & YüksekLisans\&Doktora & $\bar{X}$ & $P$ & $F$ \\
\hline Sendikalar & 4 & 3 & 24 & 2 & 2,630 & 0,0402 & 1,134 \\
\hline Odalar & 5 & 5 & 19 & 3 & 2,621 & 0,0324 & 1,553 \\
\hline $\begin{array}{l}\text { Siyasi } \\
\text { Partiler }\end{array}$ & 6 & 6 & 12 & 3 & 2,210 & 0,0595 & 1,651 \\
\hline Toplam & 15 & 14 & 65 & 8 & & & \\
\hline
\end{tabular}
düzeyinde(sendikalar, odalar ve siyasi partiler) mezun durumlarına göre bir farklılık olup olmadığını belirlemeye yönelik olarak ANOVA testine tabi tutulmuş ve sonuç olarak da anlamlı bir fark görülmüştür $(p<0.05)$. Analiz sonucunda gruplar arasında odalar alt boyutu açısından anlamlı fark bulunmazken, sendikalar ( $\mathrm{F}: 1.13, \mathrm{P}<0.05)$ ve odalar olarak (F:1.55, $\mathrm{P}<0.05$ ) alt boyutlar açısından belirlenen farkın hangi gruplar arasında olduğu tespit etmek için yapılan Tukey testinde lisans mezunlarının lise ve daha alt mezun gruplarına göre karar vermede daha etkili olduğu görülmüştür.

Tablo 4.11. Deneklerin Kent Konseyindeki Görev Durumuna Göre Kentin Hak ve Hukukunun Korunması İle İlgili Yeterli Çalışmanın Yapılıp Yapılmama Durumu

\begin{tabular}{|c|c|c|c|c|c|c|c|}
\hline \multirow{2}{*}{$\begin{array}{l}\text { Kent } \\
\text { Konseyindeki } \\
\text { Görev Durumu }\end{array}$} & \multicolumn{4}{|c|}{$\begin{array}{c}\text { Kentin hak ve hukukunun } \\
\text { korunması ile ilgili kentlinin } \\
\text { bilinçlendirilmesi yönünde yeterli } \\
\text { çalışmalar yapılıyor mu? }\end{array}$} & \multirow[t]{2}{*}{$\bar{x}$} & \multirow[t]{2}{*}{$P$} & \multirow[t]{2}{*}{$F$} \\
\hline & $\begin{array}{c}\text { Fikrim } \\
\text { yok }\end{array}$ & Kısmen & Hayır & Evet & & & \\
\hline Kent konseyi üyesi & 4 & 21 & 25 & 8 & 3,082 & 0,0533 & 2,045 \\
\hline Meclislerde görevli & 1 & 10 & 12 & 3 & 3,451 & 0,0584 & 2,740 \\
\hline
\end{tabular}




\begin{tabular}{cccccccc}
$\begin{array}{c}\text { Çalışma gruplarında } \\
\text { görevli }\end{array}$ & 0 & 6 & 0 & 1 & 2,832 & 0,0621 & 2,137 \\
\hline $\begin{array}{c}\text { Yürütme kurulunda } \\
\text { görevli }\end{array}$ & 1 & 5 & 1 & 3 & 2,012 & 0,0011 & 3,325 \\
\hline Toplam & 6 & 42 & 39 & 15 & & & \\
\hline
\end{tabular}

Katılımcıların, kent konseyinde görev konumlarıyla ilgili, kentin hak ve hukukunun korunması ile ilgili yeterli çalışma yapılmasının alt boyutları açısından farklılık gösterip göstermediğine tek yönlü Varyans Analizi (One Way ANOVA) ile bakılmıştır. Analiz sonucunda gruplar arasında kent konseyi üyesi ve meclislerde görevli alt boyutu açısından fark bulunmazken, yürütme kurulunda görevli alt boyutu açısından anlamlı fark bulunmaktadır. Çalışma gruplarında görevli $(\mathrm{F}: 2,832 \mathrm{P}<0.05)$ ve yürütme kurulunda görevli $(\mathrm{F}: 3.325, \mathrm{P}<0.01)$ alt boyutlar açısından belirlenen farkın hangi gruplar arasında olduğu tespit etmek için yapılan Tukey testinde meclislerde görevli çalışanların, hayır diyerek çalışmalara katılmadığından etkili olduğu görülmüştür.

\subsection{Araştırmanın Örneklemi}

Araştırmanın örneklemi, Adana Kent Konseyi'nin yerel yönetişim bağlamında değerlendirmesi, kent konseyinde alınan kararların karşılık bulması ve üyelerin görüşleri dâhilinde yönetişimin hayata geçirilmesi noktasında 294 üye içerisinden 120 üye ile yüz yüze görüşülerek 35 soru sorulmuş, elde edilen görüşler ve sonuçları açıklanmıştır.

Araştırma analizinde, 120 kişi üzerinde anket uygulaması yapılmış olup, yapılan anketlerin 18 'i çeşitli sayıda veri eksikliği nedeni ile değerlendirme dışı bırakılarak 102 kişi üzerinde analiz tamamlanmıştır. Örneklem sayısının belirlenmesi ise çeşitli hesaplama yöntemleri ile ortaya çıkartılan sayıya ulaşılarak \%95 anlamlıık düzeyinde 102 sayının yeterli olduğu görülmüştür. Anakütleden çekilecek örneklem hacimlerinin belirlenmesinde çeşitli yöntemler geliştirilmiştir. Bunlardan birsi de bu amaç için hazırlanmış tabloların kullanılmasıdır. Anakütle büyüklükleri ve güvenirlik düzeyine göre örneklem hacimlerinin nasıl belirleneceğine dair çeşitli kaynaklarda belirtilmiş olup buradaki örneklem sayısı da anakütle oranlaması ile belirlenmiştir (Bayram, 2009: 25).

\subsection{Araştırmanın Bulguları}

Tablo 4.12. Araştırmaya Katılan Deneklerin Kent Konseyindeki Görev Durumu

\begin{tabular}{ll}
\hline Deneklerin kent konseyindeki görev durumu & Toplam \\
\hline Kent konseyi üyesi & $71.28 \%$ \\
\hline Meclislerde görevli & $12.87 \%$ \\
\hline Çalışma gruplarında görevli & $3.96 \%$ \\
\hline Yürütme kurulunda görevli & $11.88 \%$ \\
\hline Genel Toplam & $100,00 \%$ \\
\hline
\end{tabular}

Araştırmaya katılan deneklerin \%71,28'i üye, \%12,87'si meclislerde görevli, \%3,96'sı çalışma grubunda görevli ve $\% 11,88^{\prime} i$ ise yürütme kurulunda görevli olduğunu bildirmiştir.

Tablo 4.13. Araştırmaya Katılan Deneklerin Cinsiyet Durumu

\begin{tabular}{ll}
\hline Deneklerin Cinsiyet Durumu & Toplam \\
\hline Erkek & $65,57 \%$ \\
\hline Kadın & $34,43 \%$ \\
\hline
\end{tabular}




Genel Toplam 100,00\%

Araştırmaya katılan deneklerin \%65.57'si erkek, \%34.43'ü ise kadındır. Kent Konseyleri Yönetmeliği kadınların katılımına ayrı bir önem vermesine rağmen katılımcılardan erkek sayısının kadın sayısının yaklaşık iki katı olduğu görülmektedir. Kent konseyi yönetimi, yönetmeliğin kadınlara yönelik tanımış olduğu önemin hayata geçirmesi ve kadın katılımını artıracak şekilde yeni düzenlemeleri yapması ile kentte katılım ve temsilin tam anlamı ile sağlanması yönünden önem taşıyacaktır.

Tablo 4.14. Araştırmaya Katılan Deneklerin Yaş Durumu

\begin{tabular}{ll}
\hline Deneklerin Yaş Durumu & Toplam \\
\hline $18-25$ Yaş & $2,00 \%$ \\
\hline $26-31$ Yaş & $5,00 \%$ \\
\hline $32-37$ Yaş & $5,00 \%$ \\
\hline $38-45$ Yaş & $14,00 \%$ \\
\hline 46 ve üzeri Yaş & $74,00 \%$ \\
\hline Boş & $0,00 \%$ \\
\hline Genel Toplam & $100,00 \%$ \\
\hline
\end{tabular}

Araştırmaya katılan deneklerin \%74.00'ı 46 yaş ve üzeri aralığını, \%14.00'ı 38-45 yaş aralığını, \%5'i 32-37 yaş aralığını, \%5'i 26-31 yaş aralığını ve son olarak \%2,00'ı ise 18-25 yaş aralığını göstermektedir. Ortaya çıkan sonuca göre 46 ve üzeri yaş aralığındakilerin, katılımcıların genel toplamın yarısından daha fazla olduğu ve özellikle genç nüfus oranının çok düşük olduğu görülmektedir.

Tablo 4.15. Araştırmaya Katılan Deneklerin Bölgeler Düzeyinde Memleket Durumu

\begin{tabular}{ll}
\hline Deneklerin Memleket Durumu & Toplam \\
\hline Akdeniz Bölgesi & $73,47 \%$ \\
\hline İç Anadolu Bölgesi & $7,14 \%$ \\
\hline Karadeniz Bölgesi & $4,08 \%$ \\
\hline Doğu Anadolu Bölgesi & $4,08 \%$ \\
\hline Güneydoğu Anadolu Bölgesi & $10,20 \%$ \\
\hline Ege Bölgesi & $1,02 \%$ \\
\hline (boş) & $0,00 \%$ \\
\hline Genel Toplam & $100,00 \%$ \\
\hline
\end{tabular}

Araştırmaya katılan deneklerin \%73,47'si Akdeniz Bölgesi (Adana: 64, Osmaniye: 5 , Kahramanmaraş: 2, İskenderun: 1, Hatay: 1), \%7,14'ü İç Anadolu Bölgesi (Niğde: 3, Sivas: 3, Aksaray: 1), \%4,08'i Karadeniz Bölgesi (Çorum: 1, Trabzon: 1, Samsun: 1), \%4,08'i Doğu Anadolu Bölgesi (Elazığ: 2, Erzurum: 1, Tunceli: 1), \%10,20'si Güneydoğu Anadolu Bölgesi (Gaziantep: 2, Diyarbakır: 3, Mardin: 2, Şanlıurfa: 1, Batman: 1, Adıyaman: 1), \%1,02'si Ege Bölgesi ( Kütahya:1) olarak bildirmiştir. Bu tablo, Adana'nın göç alan ve farklı yapılarda grupları barındıran bir şehir olduğu ve bu grupların da kent konseyinde temsil hakkı bulduğu sonucunu vermektedir 
Tablo 4.16. Araştırmaya Katılan Deneklerin Mesleki Dağılımı

\begin{tabular}{lc}
\hline Deneklerin Mesleki Dağılımı & Toplam \\
\hline Emekli & $18 \%$ \\
\hline Mali Müşavir & $2.9 \%$ \\
\hline İşletmeci & $14.7 \%$ \\
\hline Antrenör & $0.9 \%$ \\
\hline Öğretmen & $7.8 \%$ \\
\hline Avukat & $1.9 \%$ \\
\hline Doktor & $3.9 \%$ \\
\hline Müfettiş & $0.9 \%$ \\
\hline Serbest Çalışan & $20.5 \%$ \\
\hline Mühendis & $13.7 \%$ \\
\hline Akademisyen & $4.9 \%$ \\
\hline Öğrenci & $0.9 \%$ \\
\hline Çiftçi & $1.9 \%$ \\
\hline Mimar & $1.9 \%$ \\
\hline Diğer & $2.9 \%$ \\
\hline Genel Toplam & $100 \%$ \\
\hline
\end{tabular}

Araştırmaya katılan deneklerin, \%52.04'ü özel sektör çalışanı, \%28.57'si memur ve \%19.39'u ise emekli olduğunu belirtmiştir. Kent konseyinin çoğunluğunu serbest çalışanların oluşturduğu görülmektedir. Bunları emekliler ve mühendisler takip etmektedir. Bireyin mesleğinin katılıma etki ettiğini söylemek mümkündür. Çalışma saatlerinin esnekliğinden mesleğinin idare ile ilişki düzeyine kadar birçok nokta katılımın yoğunluğu noktasında önem arz etmektedir. Konseyin üye yapısında kendi işini yapan daha doğru ifadeyle başka bir kişinin yanında ücretli çalışan olmayanların sayısı bir hayli fazladır. Bu da çalışma saatlerindeki esnekliği beraberinde getirmiş ve aktif katılım noktasında kolaylaştırıcı etken olarak kendini göstermiştir.

Tablo 4.17. Araştırmaya Katılan Deneklerin Fiziksel Engel Durumu

\begin{tabular}{ll}
\hline Deneklerin Fiziksel Engel Durumu & Toplam \\
\hline Evet & $7,07 \%$ \\
\hline Hayır & $92,93 \%$ \\
\hline (boş) & $0,00 \%$ \\
\hline Genel Toplam & $100,00 \%$ \\
\hline
\end{tabular}

Araştırmaya katılan deneklerden, \%92.93'ü herhangi bir fiziksel engelinin olmadığını, \%7.07'si ise fiziksel bir engelinin olduğunu belirtmiştir. Kent Konseyleri Yönetmeliği engellilerin katılımına ayrı bir önem vermesine rağmen katılımcılardan engellilerin, engeli olmayanlara oranla çok düşük olduğu görülmektedir. Kent konseyi yönetimi, yönetmeliğin engellilere yönelik tanımış olduğu önemin hayata geçirmesi ve engelli katılımını artıracak şekilde yeni düzenlemeleri yapması ile kentte katılım ve temsilin sağlanması yönünden önemli bir adım atmış olacaktır. 
Tablo 4.18. Deneklerin Üye Olduğu Kurum-Kuruluş Bakımından Oransal Dağılım

\begin{tabular}{ll}
\hline Deneklerin Üyesi Olduğu Kurum ve Kuruluşlar & Toplam \\
\hline Bir Kuruluşa Üye Olanlar & $31,18 \%$ \\
\hline İki Kuruluşa Üye Olanlar & $39,78 \%$ \\
\hline Üç Kuruluşa Üye Olanlar & $19,35 \%$ \\
\hline Dört Kuruluşa Üye Olanlar & $5,38 \%$ \\
\hline Beş Kuruluşa Üye Olanlar & $3,23 \%$ \\
\hline Altı Kuruluşa Üye Olanlar & $1,08 \%$ \\
\hline (boş) & $0,00 \%$ \\
\hline Genel Toplam & $100,00 \%$ \\
\hline
\end{tabular}

Araştırmaya katılan denklerin üyesi olduğu kuruluş (Kamu Yönetimi Birimleri, Siyasi Partiler, Vakıflar, Meslek Odaları ve Birlikleri, İşçi Kuruluşları, Sivil Toplum Kuruluşları, Dernekler, Üniversiteler, Orta Öğretim Temsilcileri, Kent Konseyi Çalışma Grupları, Kent Konseyi Meclisleri ve Kozalar) durumu; bir kuruluşa üye olanlar \%31,18, iki kuruluşa üye olanlar \%39,78, üç kuruluşa üye olanlar \%19,35, dört kuruluşa üye olanlar $\% 5,38$, beş kuruluşa üye olanlar \%3,23 ve altı kuruluşa üye olanlar \%1,08 olarak bildirmiştir. Karşımıza çıkan tabloya bakıldığında katılımcıların en az bir kurum veya kuruluşa üye olduğu görülmektedir. Üyelerin en az bir kurum-kuruluşa üye olması örgüt üyeliğinin katılıma etkisini görme noktasında önemli olduğu düşünülmektedir.

Tablo 4.19. Araştırmaya Katılan Deneklerin Eğitim Durumu

\begin{tabular}{ll}
\hline Deneklerin Eğitim Durumu & Toplam \\
\hline Okuma Yazma Bilmeyen & $0,00 \%$ \\
\hline Okuma Yazma Bilen Ama Bir Okul Bitirmeyen & $0,00 \%$ \\
\hline Ilkokul & $2,00 \%$ \\
\hline Ortaokul & $4,00 \%$ \\
\hline Lise & $16,00 \%$ \\
\hline Ön Lisans & $12,00 \%$ \\
\hline Lisans & $42,00 \%$ \\
\hline Yüksek Lisans & $20,00 \%$ \\
\hline Doktora & $4,00 \%$ \\
\hline (boş) & $0,00 \%$ \\
\hline Genel Toplam & $100,00 \%$ \\
\hline
\end{tabular}

Araştırmaya katılan deneklerin, \%42,00'ı lisan, \%20,00'ı yüksek lisans, \%16,00'ı lise, \%12,00'ı ön lisana, \%4,00'ı doktora, \%4,00'ı ortaokul ve \%2,00'। da ilkokul olarak eğitim durumunu belirtmiştir. Eğitim durumuna bakıldığında kent konseyi üyelerinin eğitim durumlarının yüksek olduğu söylenebilir. Bu durumun kent konseyine katılım bilincine etki ettiğini söylemek mümkündür. Ayrıca konsey üyelerinin eğitim durumunun yüksek olması, nitelikli katılıma olumlu yönde etki eden bir husus olduğu söylenebilir.

Tablo 4.20. Araştırmaya Katılan Deneklerin Aylık Gelir Dağılımı

\begin{tabular}{ll}
\hline Deneklerin Aylık Gelir Durumu & Toplam \\
\hline 1000 Liraya Kadar & $5,15 \%$ \\
\hline $1001-2000$ & $17,53 \%$ \\
\hline
\end{tabular}




\begin{tabular}{ll}
\hline $2001-2500$ & $19,59 \%$ \\
\hline $2501-3000$ & $8,25 \%$ \\
\hline $3001-4000$ & $17,53 \%$ \\
\hline 4001 ve üzeri & $31,96 \%$ \\
\hline (boş) & $0,00 \%$ \\
\hline Genel Toplam & $100,00 \%$ \\
\hline
\end{tabular}

Araştırmaya katılan deneklerin, \%31,96'sı 4001 ve üzeri geliri, \%19,59'u 2001-2500 arası geliri, \%17,53'ü 1001-2000 arası geliri, ,\%17,53'ü 3001-4000 arası geliri, \%8,25'i 25013000 arası geliri ve \%5,15'i ise 1000 liraya kadar bir gelirinin olduğunu belirtmiştir. Ülke şartları ve asgari ücret düşünüldüğünde kent konseyi üyelerinin gelir düzeylerinin iyi durumda olduğu ve Türkiye ortalamasının üstünde bir seyir izlediği söylenebilir. Katılımcıların eğitim seviyelerinin yüksekliği gelir durumlarına da yansıdığı görülmektedir. Burada akıllara Moslow'un ihtiyaçlar hiyerarşisinden yola çıkarak belli intiyaçlar giderildikten sonra "kendini gerçekleştirme" noktasında katılımın kişiler için önem arz ettiğini söylemek mümkündür.

Tablo 4.21. Belediye Meclisine Gönderilen Kararlar Hakkında Üyelerin Bilgilendirilmesi

\begin{tabular}{ll}
\hline $\begin{array}{l}\text { Kent konseyinde görüşülüp belediye meclisine } \\
\text { gönderilen kararlar hakkında üyelere bilgilendirme } \\
\text { yapılıyor mu? }\end{array}$ & Toplam \\
\hline Fikrim yok & $0,00 \%$ \\
\hline Kısmen & $12,56 \%$ \\
\hline Hayır & $33,17 \%$ \\
\hline Evet & $54,27 \%$ \\
\hline Genel Toplam & $100,00 \%$ \\
\hline
\end{tabular}

Araştırmaya katılan deneklerin, \%54.27'si kent konseyinde görüşülüp belediye meclisine gönderilen kararlar hakkında kendilerinin bilgilendirildiğini, \%33.17'si kendilerinin bilgilendirilmediğini, $\% 12,56$ 'sı ise kendilerinin kısmen bilgilendirildiğini belirtmiştir. Katılımcıların yarısından fazlasının, kendilerinin konu ile alakalı bilgilendirildiğini söylemesi kent konseyinin şeffaf oluşunu akıllara getirirken, diğer yandan konu ile alakalı olumsuz yönde cevap verenlerin sayısının da azımsanmayacak derecede fazla olduğu dikkat çekmektedir. Yönetişimin en önemli ilkelerinden biri şeffaflıktır. Şeffaflık ilkesi uygulandığında, özel sektör, sivil toplum örgütleri ve halk kent konseyine daha fazla katılma isteği duyacaktır.

Tablo 4.22. Hemşehrilik Bilincinin Geliştirilmesine Yönelik Kent Konseyi Çabası

\begin{tabular}{ll}
\hline $\begin{array}{l}\text { Hemşehrilik bilincinin geliştirilmesine yönelik kent } \\
\text { konseyi yeteri çabayı gösteriyor mu? }\end{array}$ & Toplam \\
\hline Fikrim yok & $0,00 \%$ \\
\hline Kısmen & $17,65 \%$ \\
\hline Hayır & $31,02 \%$ \\
\hline Evet & $51,34 \%$ \\
\hline Genel Toplam & $100,00 \%$ \\
\hline
\end{tabular}

Araştırmaya katılan deneklerin \%51.34'ü hemşehrilik bilincinin geliştirilmesine yönelik kent konseyinin yeteri çabayı gösterdiğini, \%31.02'si yeterli çabayı göstermediğini ve geriye kalan $\% 17,56$ 'sı ise kent konseyinin kısmen çaba gösterdiğini belirtmiştir. Yerel halkın kentine 
sahip çıkması ve bir aidiyet duygusu hissetmesi için kent konseyinin hemşehrilik bilincinin geliştirilmesi yönünde çaba göstermesi, yerel düzeyde ortak aklın oluşturulması ve yerel yönetişimin hayat bulması yönünden önem taşımaktadır. Katılımcıların yarısından fazlasının bu yönde olumlu görüş bildirmesi önemliyken, yapılan saha çalışmasında, farklı şehir kökenli kişilerin çokluğu ve ortak Adana bilincinin yaratılması konusunda sıkıntı yaşandığı görülmüştür.

\section{Tablo 4.23. Aynı Kentte Yaşayan İnsanların Kent Konseyi Yönetimine Katılım Talebi}

\begin{tabular}{ll}
\hline $\begin{array}{l}\text { Aynı kentte yaşayan insanların kent konseyi } \\
\text { yönetimine katılma noktasında talepleri oluyor mu? }\end{array}$ & Toplam \\
\hline Fikrim yok & $0,00 \%$ \\
\hline Kısmen & $16,38 \%$ \\
\hline Hayır & $29,38 \%$ \\
\hline Evet & $54,24 \%$ \\
\hline Genel Toplam & $100,00 \%$ \\
\hline
\end{tabular}

Araştırmaya katılan deneklerin, \%54.24'ü aynı kentte yaşayan insanların kent konseyi yönetimine katılma noktasında taleplerinin olduğunu, \%29.38'i yönetime katılma noktasında bir talebin olmadığını ve $\% 16,38$ 'i ise konuyla alakalı taleplerin kısmen olduğunu belirtmiştir. Aynı kentte yaşayan insanların kent konseyi yönetimine katılım taleplerinin olması önemlidir. Çünkü sorunların çözümü noktasında insanların sorumluluk almak istemeleri, yerel yönetişimin hayata geçmesi ve yerel demokrasinin gelişimi adına olumlu bir durumdur.

Tablo 4.24. Aynı Kentte Yaşayan İnsanların Kent Konseyi Yönetimine Katılım Duyarlılığı

\begin{tabular}{ll}
\hline $\begin{array}{l}\text { Aynı kentte yaşayan insanların kent konseyi } \\
\text { yönetimine katılma noktasında duyarlı olduğunu } \\
\text { düşünüyor musunuz? }\end{array}$ & $3,06 \%$ \\
\hline Fikrim yok & $27,55 \%$ \\
\hline Kısmen & $45,92 \%$ \\
\hline Hayır & $23,47 \%$ \\
\hline Evet & $0,00 \%$ \\
\hline (boş) & \\
\hline
\end{tabular}

Araştırmaya katılan deneklerin, \%45.92'si aynı kentte yaşayan insanların kent konseyi yönetimine katılma noktasında duyarlı olmadığını, \%27,55'i insanların kısmen duyarlı olduğunu, \%23,47'si insanların duyarlı olduğunu ve \%3,06'sı ise konu ile alakalı bir fikirlerinin olmadığını belirtmiştir. Buradan, aynı kentte yaşayan insanların kent konseyi yönetimine katılım noktasında duyarlı olmadığı sonucu çıkmaktadır. Bir önceki tabloda ise katılımcılar aynı kentte yaşayan insanların kent konseyi yönetimine katılım noktasında taleplerinin olduğunu belirtmişlerdi. Dikkat edildiğinde bu iki sonuç arasında bir tezatlığın olduğu görülmektedir. Çünkü bir yandan insanların katılım noktasında duyarsız olunduğu, diğer yandan da yönetime katılım noktasında taleplerinin olduğu söylenmektedir. Genel olarak düşünüldüğünde, duyarsız insanların katılım noktasındaki talebinden bahsedilemez, böyle bir ihtimal olsa bile bunun oranı çok düşük olacaktır. Burada kent konseyine düşen, halkın katılım duyarlııı̆ını geliştirecek mekanizmalara yer vermesi ve kendini geliştirmesidir. 
Tablo 4.25. Kentin Hak ve Hukukunun Korunması ile Kentlinin Bilinçlendirilmesi Yönünde Gösterilen Çaba

\begin{tabular}{ll}
\hline $\begin{array}{l}\text { Kentin hak ve hukukunun korunması ile ilgili kentlinin } \\
\text { bilinçlendirilmesi yönünde yeterli çalışmalar yapılıyor } \\
\text { mu? }\end{array}$ & Toplam \\
\hline Fikrim yok & $6,00 \%$ \\
\hline Kısmen & $39,00 \%$ \\
\hline Hayır & $32,00 \%$ \\
\hline Evet & $23,00 \%$ \\
\hline (boş) & $0,00 \%$ \\
\hline Genel Toplam & $100,00 \%$ \\
\hline
\end{tabular}

Araştırmaya katılan deneklerin, \%39.00'ı Kentin hak ve hukukunun korunması ile ilgili kentlinin bilinçlendirilmesi yönünde yeterli çalışmaların kısmen yapıldığını, \%32.00'ı yeterli çalışmaların yapılmadığını, \%23,00'ı yeterli çalışmaların yapıldığını ve \%6,00'ı ise konu ile alakalı bir fikirlerinin olmadığını belirtmiştir. Katılımcıların çoğunluğu soruya "kısmen" cevabını verirken, bunun hemen arkasından "hayır" cevabının geldiği ve genel olarak olumsuz bir sonucun ortaya çıktığı görülmektedir. "Kent Konseyinin Faaliyetleri" başlığı altında değinilen çalışmalara bakıldığında, buradan çıkan sonuçları teyit edici bir tablo ortaya çıkmaktadır. Kent Konseyleri Yönetmeliği'nin önem verdiği hususlardan biri olmasına rağmen Adana Kent Konseyi'nin konuya fazla eğilmemesi önemli bir eksikliktir. Kent konseyi tarafından bilinçlendirilen kentli, bir taraftan kentin hak ve hukukunu koruyacak diğer taraftan konseyin yükünü hafifletecektir.

Tablo 4.26. Toplantılarda Dile Getirilen Görüşlerin Belediye Tarafından Dikkate Alınması

\begin{tabular}{ll}
\hline $\begin{array}{l}\text { Toplantılarda dile getirdiğiniz görüşler } \\
\text { tarafından yeterince dikkate alınıyor mu? }\end{array}$ & Toplam \\
\hline Fikrim yok & $0,00 \%$ \\
\hline Kısmen & $23,31 \%$ \\
\hline Hayır & $34,36 \%$ \\
\hline Evet & $42,33 \%$ \\
\hline Genel Toplam & $100,00 \%$ \\
\hline
\end{tabular}

Araştırmaya katılan deneklerin, \%42,33'ü toplantılarda dile getirilen görüşlerin belediye tarafından yeterince dikkate alındığını, \%34.36'sı görüşlerinin yeterince dikkate alınmadığını ve $\% 23,31^{\prime} i$ de görüşlerinin kısmen dikkate alındığını belirtmiştir. Kent Konseylerinin almış olduğu kararları uygulatabilme gücü bulunmamaktadır. Yönetmeliğe göre kent konseylerinin kararları belediye meclislerinde sadece tavsiye niteliğinde görüşülebilmektedir. Kent konseylerinde katılım önemli bir olgudur. Alınmış bir kararın belediye tarafından dikkate alınamayacağı düşüncesinin oluşması katılımı düşürecektir. Dile getirilen görüşlerin yeterince dikkate alınacağı düşüncesinin oluşması ise katılımın artırılması yönünde olumlu bir sonuç doğuracaktır.

Tablo 4.27. Kent Konseyinin Temsil Platformu Taşıma Özelliği

Kent konseyi mevcut haliyle geniş bir temsil
platformu özelliği taşıyor mu?




\begin{tabular}{ll}
\hline Fikrim yok & $0,00 \%$ \\
\hline Kısmen & $12,68 \%$ \\
\hline Hayır & $28,17 \%$ \\
\hline Evet & $59,15 \%$ \\
\hline Genel Toplam & $100,00 \%$ \\
\hline
\end{tabular}

Araştırmaya katılan deneklerin, \%59.15'i kent konseyinin mevcut haliyle geniş bir temsil platformu özelliği taşıdığını, \%28.17'si geniş bir temsil platformu özelliği taşımadığını ve $\% 12,68^{\prime} i$ ise konseyin geniş bir temsil platformu özelliğini kısmen taşıdığını belirtmiştir. Kent konseylerinin en önemli özelliği yerelde demokratik yönetişimi sağlamalarıdır. Yerel demokratik yönetişim, birbirine zıt gibi görünen, kentin bütün renklerinin aynı potada erimesiyle oluşabilmektedir. Adana Kent Konseyi genel kur listesi incelendiğinde farklı düşünce yapılarındaki kurum ve kuruluşların konseyin bünyesinde yer aldığı görülmektedir. Yapılan saha çalışması tabloda çıkan sonucu teyit edicidir.

Tablo 4.28. Kurul Toplantıları Dışında Üyelerle Toplantıların Gerçekleştirilme Durumu

\begin{tabular}{ll}
\hline $\begin{array}{l}\text { Kurul toplantıları dışında kent konseyi üyelerle } \\
\text { toplantılar gerçekleştiriyor mu? }\end{array}$ & Toplam \\
\hline Fikrim yok & $0,00 \%$ \\
\hline Kısmen & $38,06 \%$ \\
\hline Hayır & $32,84 \%$ \\
\hline Evet & $29,10 \%$ \\
\hline Genel Toplam & $100,00 \%$ \\
\hline
\end{tabular}

Araştırmaya katılan deneklerin, \%38.06'sı kurul toplantıları dışında kent konseyinin üyelerle kısmen toplantılar gerçekleştirdiğini, \%32.84'ü konseyin üyelerle toplantılar gerçekleştirilmediğini ve son olarak $\% 29,10^{\prime} u$ ise konseyin üyelerle toplantılar gerçekleştirdiğini belirtmiştir. Kent konseyi, üyelerinin konseye karşı aidiyet duygularını beslemesi ve konseye katılımlarının artırıması için sürekli toplantılar gerçekleştirmesi gereklidir. Adana Kent Konseyinin kurul toplantıları dışında toplantılar gerçekleştirmemesinin bazı nedenleri üzerinde düşünüldüğünde akla üç ihtimal gelmektedir: 1-Konsey aktif çalışmıyordur, dolayısıyla toplanma gereği duyacak bir şey yoktur. 2-Konsey yaptığı iş ve işlemler hakkında üyelerle toplantılar yapma gereği duymuyordur, dar dairede işlerini hallediyordur. 3-Üyelerin toplantılara olan ilgisizliklerinden dolayı konsey ekstra bir toplantı yapma gereği duymuyordur. Yapılan alan araştırmasında 3'üncü maddenin daha ağır bastığı, üyelerin ekstra toplantılar yapmayı angarya bir iş olarak gördüğü görülmüştür.

Tablo 4.29. Kent Konseyinin Halka Tanıtılması

\begin{tabular}{ll}
\hline Kent konseyi halka yeterince tanıtılıyor mu? & Toplam \\
\hline Fikrim yok & $0,00 \%$ \\
\hline Kısmen & $11,92 \%$ \\
\hline Hayır & $53,89 \%$ \\
\hline Evet & $34,20 \%$ \\
\hline Genel Toplam & $100,00 \%$ \\
\hline
\end{tabular}

Araştırmaya katılan deneklerin $\% 53.89$ 'u kent konseyinin halka yeterince tanıtılmadığını; \%11.92'si kısmen tanıtıldığını ve \%34.20'si ise konseyin halka yeterince 
tanıtıldığını belirtmektedir. Yönetişim modelinde özel sektörün ve sivil toplum kuruluşlarının, halkı temsilen karar alma süreçlerine katılması bu modelin daha demokratik bir yapıyı sergilediği şeklinde yorumlanmaktadır. Ancak katılımın yeteri kadar demokratik olup olmadığı tartışmalıdır. Dolayısıyla karar alma süreçlerinde geniş halk kitlelerinin doğrudan katılımının söz konusu olabilmesi için, kent konseyinin halk tarafından yeteri kadar bilinmesi gereklidir. Burada görev kent konseyine düşmektedir. Yeteri kadar tanıtım çalışması ile halk kent konseyleri hakkında bilinçlendirilmelidir.

\section{Tablo 4.30. Alınan Kararların Belediye Tarafından Uygulanması}

\begin{tabular}{ll}
\hline $\begin{array}{l}\text { Kent konseyinde alınan kararlar belediye tarafından } \\
\text { uygulanıyor mu? }\end{array}$ & Toplam \\
\hline Fikrim yok & $0,00 \%$ \\
\hline Kısmen & $39,53 \%$ \\
\hline Hayır & $18,60 \%$ \\
\hline Evet & $41,86 \%$ \\
\hline Genel Toplam & $100,00 \%$ \\
\hline
\end{tabular}

Araştırmaya katılan deneklerden $\% 41.86$ 'sı kent konseyinde alınan kararların belediye tarafından uygulandığını, \%18.60'ı alınan kararların uygulanmadığını ve \%39.53'ü ise kararların kısmen uygulandığını belirtmiştir. Kent Konseylerine belediyelerce aktarılan finansmanın yarattığı mali bağımlılık konseylerin hareket alanını daraltmaya ve asli vazifeleri olan yerel yönetişimi hayat geçirmeye engel olmaktadır. Mali bağımlılık kent konseylerini belediyelerin parti politikaları doğrultusunda kararlar almaya mecbur bırakmaktadır. Bu durum bir yandan alınan kararların belediye meclislerinde onaylanmasını kolaylaştırırken, diğer yandan ise konseylerin asli vazifelerini yapmalarını zorlaştırmaktadır.

\section{Tablo 4.31. Kent Konseyinin Demokratik Katılım Açısından Yeterli Görülme Durumu}

\begin{tabular}{ll}
\hline $\begin{array}{l}\text { Kent konseyini demokratik katılım açısından yeterli } \\
\text { görüyor musunuz? }\end{array}$ & Toplam \\
\hline Fikrim yok & $0,00 \%$ \\
\hline Kısmen & $12,08 \%$ \\
\hline Hayır & $38,65 \%$ \\
\hline Evet & $49,28 \%$ \\
\hline Genel Toplam & $100,00 \%$ \\
\hline
\end{tabular}

Araştırmaya katılan deneklerin, \%49.28'i Kent konseyini demokratik katılım açısından yeterli gördüklerini, \%38.65'i yeterli görmediklerini ve $\% 12,08$ 'i ise demokratik açıdan kısmen yeterli gördüklerini belirtmiştir. Katılımcılar kent konseyini demokratik katılım açısından yeterli bulmaktadır. Konu ile alakalı olarak, Gümüş'ün (2009: 67) Tuzla Kent Konseyi'ne yaptığı anket çalışmasında, katılımcılar ilgili soruya cevaben, kent konseyinin demokratik katılım açısından "daha da geliştirilmesi gerektiği" yönünde görüş bildirmişlerdir. İki kent konseyinden çıkan sonuca bakılacak olursa, Adana Kent Konseyi'nin Tuzla Kent Konseyinden daha demokratik olarak algılandığıdır. Burada dikkat edilmesi gereken husus, Tuzla Kent Konseyi'nde yapılan anketin 2009 yılına ait olduğu ve yaptığımız anketle arasında yaklaşık yedi yıl gibi bir sürenin olduğudur. Aradan geçen süre Tuzla Kent Konseyine olan algıyı değiştirmiş olabilir. Yaptığımız çalışmayla ilgili olarak, Adana Kent Konseyi genel kuruluna bakıldığında şehrin bütün renklerini bünyesinde barındırmaya çalıştığı görülmektedir. Ayrıca 
yapılan alan araştırmasında görüşülen üyelerin yılda en az bir kez kent konseyinin çalışmalarına katıldıklarını ifade etmiş olmaları, konseyin demokratik katılım açısından temsilini göstermektedir. Katılımcıların görüşlerinin de bu yönde olduğu tablodan anlaşılmaktadır.

Tablo 4.32. Kent Konseyine Katılım ve Yönetimi Etkileyebilme Gücü

\begin{tabular}{ll}
\hline $\begin{array}{l}\text { Üyelerin kent konseyine katılımını ve yönetimi } \\
\text { etkileyebilme gücünü yeterli buluyor musunuz? }\end{array}$ & Toplam \\
\hline Fikrim yok & $0,00 \%$ \\
\hline Kısmen & $15,34 \%$ \\
\hline Hayır & $56,08 \%$ \\
\hline Evet & $28,57 \%$ \\
\hline Genel Toplam & $100,00 \%$ \\
\hline
\end{tabular}

Araştırmaya katılan deneklerin, \%56.08'i üyelerin kent konseyine katılımını ve yönetimi etkileyebilme gücünü yeterli bulmadığını, \%28.57'si yeterli bulduğunu ve \%15,34'ü ise kısmen yeterli bulduğunu belirtmiştir. Katılımın fazlalığı demokratik açıdan olumlu bir gösterge olarak yorumlanmaktadır. Demokratik taleplerin seslendirileceği varsayılan kent konseyi yeteri kadar katılım çekemediği görülmektedir. Üyelerin katılımı ve yönetimi etkileyebilme gücü birbiriyle bağlantılı bir durumdur. Yönetimi etkileyebileceğine inanmayan veya daha önce böyle bir teşebbüste bulunup olumsuz sonuç alan üye kent konseyine katılım noktasında mesafeli duracaktır. Ayrıca, ortaya konulan sorunlara getirilen çözüm önerilerini uygulatma gücü bulunmayan kent konseyine de katılım yeterli olmayacaktır.

Tablo 4.33. Halkın Meclis Kararlarına Katılımının Yeterliliği

\begin{tabular}{ll}
\hline $\begin{array}{l}\text { Halkın meclis kararlarına katılımını yeterli buluyor } \\
\text { musunuz? }\end{array}$ & Toplam \\
\hline Fikrim yok & $0,00 \%$ \\
\hline Kısmen & $11,36 \%$ \\
\hline Hayır & $78,41 \%$ \\
\hline Evet & $10,23 \%$ \\
\hline Genel Toplam & $100,00 \%$ \\
\hline
\end{tabular}

Araştırmaya katılan deneklerin, \%78.41'i halkın meclis kararlarına katılımını yeterli bulmadığını, \%11,36'sı kısmen yeterli bulduğunu ve \%10,23'ü ise yeterli bulduğunu belirtmiştir. Yapılan literatür çalışmasında Adana da halkın çoğu bırakın kent konseyi kararlarına katılımı, konseyin varlığından bile habersizdir. Daha önce de ifade edildiği gibi Adana Kent Konseyi halk katılımını gerçekleştirebilmek için tanıtım çalışmalarını hayata geçirmelidir. Çünkü halkın dâhil olmadığı bir yönetişimin başarılı bir şekilde devam etmesi mümkün değildir.

Tablo 4.34. Kent Konseyi Kararlarının Belediye Meclis Gündemini Etkilemesi

\begin{tabular}{ll}
\hline $\begin{array}{l}\text { Kent konseyinin almış olduğu kararlar belediye meclis } \\
\text { gündemini etkiliyor mu? }\end{array}$ & Toplam \\
\hline Fikrim yok & $0,00 \%$ \\
\hline Kısmen & $21,38 \%$ \\
\hline Hayır & $41,38 \%$ \\
\hline
\end{tabular}




\begin{tabular}{ll}
\hline Evet & $37,24 \%$ \\
\hline Genel Toplam & $100,00 \%$ \\
\hline
\end{tabular}

Araştırmaya katılan deneklerin, \%41,38'i kent konseyinin almış olduğu kararların belediye meclis gündemini etkilemediğini, \%37,24'ü etkilediğini ve $\% 21,38^{\prime} i$ ise kısmen etkilediğini belirtmiştir. Yönetmelik gereği kent konseyinin almış olduğu kararların tavsiye niteliğinde olması, konseyin hesap sorabilmesini engellemekte ve aldığı kararları uygulatabilme gücünün bulunmaması ise etki gücünü düşürmektedir. Bütün bunlar, konseyin belediye tarafından yeterince dikkate alınmamasına neden olmaktadır.

Tablo 4.35. Taleplerin Kent Konseyi Tarafından Dikkate Alınması

\begin{tabular}{ll}
\hline $\begin{array}{l}\text { Talepleriniz kent konseyi tarafından dikkate alınıyor } \\
\text { mu? }\end{array}$ & Toplam \\
\hline Fikrim yok & $12,00 \%$ \\
\hline Kısmen & $34,00 \%$ \\
\hline Hayır & $17,00 \%$ \\
\hline Evet & $37,00 \%$ \\
\hline (boş) & $0,00 \%$ \\
\hline Genel Toplam & $100,00 \%$ \\
\hline
\end{tabular}

Araştırmaya katılan deneklerin, \%37.00'ı taleplerinin kent konseyi tarafından dikkate alındığını, \%17.00'ı taleplerinin dikkate alınmadığını, \%34,00'ı taleplerinin kısmen dikkate alındığını ve \%12,00'ı ise konu ile alakalı bir fikirlerinin olmadığını belirtmişlerdir. Konsey kendi üyelerinin taleplerini dikkate alması olumlu bir durumken, talepleri uygulayacak bir gücünün olmaması da olumsuz bir durumdur. Birbiriyle bağlantılı olan bu iki ilişkiye göre uygulama gücü olmayan konseye belli bir müddet sonra talep isteği düşme eğilimi gösterecektir.

Tablo 4.36. Kent Konseyi Bünyesinde Bulunan Farklı Kesimlerin Görüşünün Alınması

\begin{tabular}{ll}
\hline $\begin{array}{l}\text { Kent konseyi karar alırken bünyesinde bulunan farklı } \\
\text { kesimlerin görüşünü alıyor mu? }\end{array}$ & Toplam \\
\hline Fikrim yok & $0,00 \%$ \\
\hline Kısmen & $11,00 \%$ \\
\hline Hayır & $23,00 \%$ \\
\hline Evet & $66,00 \%$ \\
\hline Genel Toplam & $100,00 \%$ \\
\hline
\end{tabular}

Araştırmaya katılan deneklerin, \%66,00'ı kent konseyinin karar alırken bünyesinde bulunan farklı kesimlerin görüşünün aldığını, \%23,00'ı farklı kesimlerin görüşünün alınmadığını ve \%11,00'ı ise farklı kesimlerin görüşünün kısmen alındığını belirtmiştir. Konseyin kurum içi demokratik göstergesine delil olarak bünyesinde bulundurduğu farklı kesimlerin karar alma sürecine dahil edilmesidir. Bu açıdan ortaya çıkan sonuç (\%66) olumlu bir göstergedir.

Tablo 4.37. Kent Konseyinin Siyasi Düşünce Farklılıklarının Etkisinde Kalma Durumu

Kent Konseyi karar alma sürecinde siyasi düşünce farklılıklarının etkisinde kalıyor mu?

Toplam 


\begin{tabular}{ll}
\hline Fikrim yok & $0,00 \%$ \\
\hline Kısmen & $8,50 \%$ \\
\hline Hayır & $42,00 \%$ \\
\hline Evet & $49,50 \%$ \\
\hline Genel Toplam & $100,00 \%$ \\
\hline
\end{tabular}

Araştırmaya katılan deneklerin, \%49,50'si kent konseyinin karar alma sürecinde siyasi düşünce farklılıklarının etkisinde kaldığını, \%42.00'ı siyasi düşünce farklılıklarının etkisinde kalmadığını ve \%8,50'si ise kısmen kaldığını belirtmiştir. Kent konseyleri üzerine yapılan alan araştırmalarına bakıldığında genel olarak konseylerin bağlı oldukları belediyelerin parti politikalarının etkisinde kaldığı görülmektedir. Kent Konseyleri Yönetmeliği, konseylerin finansman, personel, mekân vd. ihtiyaçlarını belediyelerden karşılanma yolunu gösterdiğinden, konseyleri adeta bağlı oldukları belediyelerin parti politikaları yönünde tercih yapmaya mecbur bırakmaktadır. Bu durum, kent konseyine olan katılımı, toplantılara olan devamlılı̆ı ve ilgiyi olumsuz yönde etkilemektedir.

Tablo 4.38. Kent Konseyinin Eylem ve İşlemleri Hakkında Yapılan İtirazların Dikkate Alınması

\begin{tabular}{ll}
\hline $\begin{array}{l}\text { Kent Konseyinin eylem ve işlemleri } \\
\text { yaptığınız itirazlar dikkate alınıyor mu? }\end{array}$ & Toplam \\
\hline Fikrim yok & $0,00 \%$ \\
\hline Kısmen & $19,18 \%$ \\
\hline Hayır & $19,18 \%$ \\
\hline Evet & $61,64 \%$ \\
\hline Genel Toplam & $100,00 \%$ \\
\hline
\end{tabular}

Araştırmaya katılan deneklerin, \%61,64'ü kent konseyinin eylem ve işlemleri hakkında yaptıkları itirazların dikkate alındığını, \%19,18'i itirazlarının dikkate alınmadığını ve bir başka \%19,18'i ise itirazlarının kısmen dikkate alındığını belirtmiştir. İtirazlarının dikkate alınması üyelerin konseye karşı aidiyet beslemesine, konseye katılımın artmasına ve yerel yönetişimin hızlanmasına yol açması bakımından önem taşımaktadır.

Tablo 4.39. Kent Konseyinin Eylem ve İşlemlerinde Yakın Bir İlişki İçine Girdiği Düşünülen Kurum ve Kuruluşlar

\begin{tabular}{ll}
\hline $\begin{array}{l}\text { Kent Konseyi eylem ve işlemlerinde aşağıdaki } \\
\text { birimlerden hangisi ile daha yakın bir ilişki içine } \\
\text { girmektedir? }\end{array}$ & Toplam \\
\hline Fikrim yok & $0,00 \%$ \\
\hline Tüm kurumlarla İlişkileri aynı düzeydedir & $13,29 \%$ \\
\hline Sivil toplum kuruluşları & $48,10 \%$ \\
\hline Özel sektör & $5,70 \%$ \\
\hline Kamu kurumları & $32,91 \%$ \\
\hline Genel Toplam & $100,00 \%$ \\
\hline
\end{tabular}

Araştırmaya katılan deneklerin, \%48,10'u kent konseyinin eylem ve işlemlerinde sivil toplum kuruluşlarıyla daha yakın bir ilişki içine girdiğini, \%32.91'i kent konseyinin kamu kurumları ile daha yakın bir ilişki içine girdiğini, \%5,70’i özel sektör ile daha yakın bir ilişki 
içine girdiğini ve \%13,29'ı ise konseyin tüm kurumlarla ilişkilerin aynı düzeyde olduğunu belirtmiştir. Yönetişimin üç ayağı vardır; bunlar özel sektör, sivil toplum kuruluşları ve kamu kurumlarıdır. Adana Kent Konseyi bu üç ayağı oluşturan kurumlarla dengeli çalıştığı sürece yönetişimi sağlayabildiğinden söz edilebilir. Tablodan çıkan sonuca bakıldığında, yönetişimin bir ayağı olan özel sektörle ilişkilerinin çok kısıtlı olduğu diğer taraftan sivil toplum kuruluşlarına ağırlık verildiği görülmektedir. Adana da yerel yönetişimin hayat bulması ilgili kurumlarla dengeli hareket edilmesi ile mümkün olacaktır.

Tablo 4.40. Alınan Kararlarda Büyükşehir Belediyesinin Etkisinde Kalınma Durumu

\begin{tabular}{ll}
\hline $\begin{array}{l}\text { Kent Konseyi almış olduğu kararlarda büyükşehir } \\
\text { belediyesinin etkisinde kalıyor mu? }\end{array}$ & Toplam \\
\hline Fikrim yok & $15,00 \%$ \\
\hline Kısmen & $18,00 \%$ \\
\hline Hayır & $17,00 \%$ \\
\hline Evet & $50,00 \%$ \\
\hline (boş) & $0,00 \%$ \\
\hline Genel Toplam & $100,00 \%$ \\
\hline
\end{tabular}

Araştırmaya katılan deneklerin, \%50.00'ı kent konseyinin almış olduğu kararlarda büyükşehir belediyesinin etkisinde kaldığını, \%17.00'ı kent konseyinin büyükşehir belediyesinin etkisinde kalmadığını, \%18,00' kısmen etkisinde kaldığını ve \%15,00'ı ise konu ile alakalı bir fikrinin olmadığını belirtmiştir. Kent Konseyleri Yönetmeliği, konseylerin finansman, personel, mekân vd. ihtiyaçlarını belediyelerden karşılanma yolunu gösterdiğinden, kent konseyleri adeta bağlı oldukları belediyelerin parti politikaları yönünde tercih yapmaya mecbur bırakılmışlardır. Buradan çıkan sonuç, genel kabul gören bu gerçeğin Adana Kent Konseyi özelinde de geçerli olduğunu göstermektedir.

Tablo 4.41. Yapılan Harcamalarla İlgili Üyelerin Bilgilendirilmesi

\begin{tabular}{ll}
\hline $\begin{array}{l}\text { Kent Konseyi yaptığı harcamalarla ilgili üyeleri } \\
\text { bilgilendiriyor mu? }\end{array}$ & Toplam \\
\hline Fikrim yok & $15,00 \%$ \\
\hline Kısmen & $16,00 \%$ \\
\hline Hayır & $52,00 \%$ \\
\hline Evet & $17,00 \%$ \\
\hline (boş) & $0,00 \%$ \\
\hline Genel Toplam & $100,00 \%$ \\
\hline
\end{tabular}

Araştırmaya katılan deneklerin, \%52.00'ı kent konseyinin yaptığı harcamalarla ilgili üyeleri bilgilendirmediğini, \%17,00'ı üyelerin bilgilendirildiğini, \%16,00'ı üyelerin konu ile alakalı kısmen bilgilendirildiğini ve \%15,00'ı ise konu ile alakalı bir fikirlerinin olmadığını belirtmiştir. Kent konseyinin yaptığı harcamalar şeffaflık ilkesi gereği göz önünde ve hesap verilebilir olmalıdır. Şeffaflık, yönetime olan güveni artırırken diğer yandan güvene dayalı oluşan ortam katılımı artıracak ve yönetişimin hayata geçmesi hız kazanacaktır. Adana Kent Konseyi yönetimi, üyelerinin bu konuda bir talebi olmasa bile yıl sonunda yapılan harcamaları ve bütçeye aktarılan kaynağı genel kurulla paylaşmalı ve hesap hareketleri hakkında bilgilendirme yapmalıdır. 
Tablo 4.42. Kent Konseyi Bünyesinde Yer Alan Birimlerin Uyum İçinde Çalışması

\begin{tabular}{ll}
\hline $\begin{array}{l}\text { Kent Konseyi bünyesinde yer alan birimler(meclisler, } \\
\text { çalışma grupları vd.) uyum içinde çalışıyor mu? }\end{array}$ & Toplam \\
\hline Fikrim yok & $0,00 \%$ \\
\hline Kısmen & $16,07 \%$ \\
\hline Hayır & $10,71 \%$ \\
\hline Evet & $73,21 \%$ \\
\hline Genel Toplam & $100,00 \%$ \\
\hline
\end{tabular}

Araştırmaya katılan deneklerin, \%73.21'i kent konseyi bünyesinde yer alan birimlerin uyum içinde çalıştıklarını, \%10.71'i birimlerin uyum içinde çalışmadıklarını ve \%16,07'si ise birimlerin kısmen uyumlu çalıştığını belirtmiştir. Katılımcılar büyük bir oranla, konseyde yer alan birimlerin uyum içinde çalıştığını belirtmektedir. Yerel yönetişimin hızla yayılması, konseyde yer alan uzman birimlerin uyum içinde çalışmasına da bağlıdır. Bundan dolayı Adana Kent Konseyi'ndeki birimlerin uyum içinde çalışması yerel yönetişimin hızla yayılması açısından önem taşımaktadır.

Tablo 4.43. Kent Konseyi Bütçesine Ayrılan Ödeneğin Yerel Yönetişimin Sağlanması Yönünden Harcanması

\begin{tabular}{ll}
\hline $\begin{array}{l}\text { Kent konseyi bütçesine ayrılan ödenek yerel } \\
\text { yönetişimin sağlanması yönünden harcanıyor mu? }\end{array}$ & Toplam \\
\hline Fikrim yok & $48,00 \%$ \\
\hline Kısmen & $10,00 \%$ \\
\hline Hayır & $16,00 \%$ \\
\hline Evet & $26,00 \%$ \\
\hline (boş) & $0,00 \%$ \\
\hline Genel Toplam & $100,00 \%$ \\
\hline
\end{tabular}

Araştırmaya katılan deneklerin, \%48.00'ı konu ile alakalı bir fikirlerinin olmadığını, \%26,00'ı ödeneğin yerel yönetişimin sağlanması yönünde harcandığını, \%16,00’ı ödeneğin yerel yönetişimin sağlanması yönünde harcanmadığını ve \%10,00’ ise ödeneğin yerel yönetişimin sağlanması yönünde kısmen harcandığını belirtmiştir. Üyelerin konu ile alakalı fikirlerinin olmamasının temel nedeni kent konseyine verilen ödeneklerin belediye bütçesi içinde yer almasıdır. Dolayısıyla bilgilendirmenin öncelikle belediyeler tarafından yapılması gereklidir.

Tablo 4.44. Yerel Yönetişimin Hayata Geçirilmesi Noktasında Kent Konseyinin Yeterli Bulunması

\begin{tabular}{ll}
\hline $\begin{array}{l}\text { Yerel yönetişimin hayata geçirilmesi noktasında kent } \\
\text { konseyini yeterli buluyor musunuz? }\end{array}$ & Toplam \\
\hline Fikrim yok & $0,00 \%$ \\
\hline Kısmen & $19,08 \%$ \\
\hline Hayır & $56,65 \%$ \\
\hline Evet & $24,28 \%$ \\
\hline Genel Toplam & $100,00 \%$ \\
\hline
\end{tabular}


Araştırmaya katılan deneklerin, $\% 56,65$ 'i yerel yönetişimin hayata geçirilmesi noktasında kent konseyini yeterli bulmadıklarını, \%24,28'i kent konseyini yeterli bulduklarını ve $\% 19,08^{\prime} i$ ise kent konseyini kısmen yeterli bulduklarını belirtmişlerdir. Bir önceki soruda (Tablo 6.43) katılımcılar kent konseyi bütçesine ayrılan ödeneğin yerel yönetişimin sağlanmasına yönelik fikirlerinin olmadığını beyan ederken, bu soruya ise büyük çoğunlukla (\%56.65) "hayır" cevabını vererek olumsuz yönde beyanda bulunmuşlardır. Dikkat edilirse, bu sorunun mantığı bir öncekine yakın olmasına rağmen çoğunluğunun soruya hayır cevabı vermesi katılımcıların yapılan çalışmaları yerel yönetişimle bağdaştırmada sıkıntı çektiğini ve kent konseyini yeteri kadar bilemediklerini ortaya koymuştur.

Tablo 4.45. Kent Konseyinin Yönetişimi Sağlaması

\begin{tabular}{ll}
\hline Kent Konseyi yönetişimi sağlıyor mu? & Toplam \\
\hline Fikrim yok & $0,00 \%$ \\
\hline Kısmen & $19,88 \%$ \\
\hline Hayır & $29,24 \%$ \\
\hline Evet & $50,88 \%$ \\
\hline Genel Toplam & $100,00 \%$ \\
\hline
\end{tabular}

Araştırmaya katılan deneklerin, \%50,88'i kent konseyinin yönetişimi sağladığını, $\% 29,24$ 'ü kent konseyinin yönetişimi sağlamadığını ve $\% 19,88^{\prime} i$ ise kent konseyinin yönetişimi kısmen sağladığını belirtmiştir. Bir önceki soruda (Tablo 6.44) katılımcılar kent konseyini yerel yönetişimi sağlama konusunda yeterli bulmazken; bu soru da ise kent konseyini yeterli bulmaları, katılımcıların yönetişim kavramını yeteri bilmediklerini ortaya koymaktadır.

\section{Tablo 4.46. Kent Konseyi Kararları Üzerinde Etkili Olduğu Düşünülen Kurum ve Kuruluşlar}

\begin{tabular}{ll}
\hline $\begin{array}{l}\text { Kent konseyinin kararları üzerinde en çok hangi kesim } \\
\text { etkilidir? }\end{array}$ & Toplam \\
\hline Odalar & $2,20 \%$ \\
\hline Sendikalar & $12,09 \%$ \\
\hline Siyasi Partiler & $28,57 \%$ \\
\hline Belediye & $38,46 \%$ \\
\hline Sivil Toplum Kuruluşları & $1,10 \%$ \\
\hline Muhtarlar & $17,58 \%$ \\
\hline (boş) & $0,00 \%$ \\
\hline Genel Toplam & $100,00 \%$ \\
\hline
\end{tabular}

Araştırmaya katılan deneklerin, \%38,46'sı belediyelerin, \%28,7'si siyasi partilerin, $\% 17,58^{\prime} \mathrm{i}$ muhtarların, $\% 12,09^{\prime}$ u sendikaların, \%2,20'si odaların ve $\% 1,10^{\prime} u$ ise sivil toplum kuruluşlarının kent konseyi kararları üzerinde etkili olduğunu belirtmiştir. Kent konseyi üyeleri belediyenin ve ardından da siyasi partilerin etkili olduklarını düşünmektedirler. Belli'nin (2016: 133) doktora çalışması kapsamında Büyükşehir Belediyeleri genelinde kent konseyi üyelerine uyguladığı anket sonucuna göre kent konseyi üyeleri böyle bir soruya "kent konseyi meclis ve çalışma gruplarının" daha etkili olduğu görüşünü beyan etmişlerdir. Büyükşehir belediyeleri genelinde çıkan bu sonucun Adana özeline uymadığı ortaya çıkmaktadır. Adan özelinde çıkan sonuç, belediyenin ve siyasi partilerin kent konseyi kararları üzerinde kurumsal güçlerini baskı aracı haline getirmeleri neticesinde etkili olduklarını 
düşündürürken; dikkat çeken diğer bir husus da yönetişimin bir ayağını oluşturan sivil toplum kuruluşlarının etki güçlerinin çok zayıf olduğunun düşünülmesidir. Ayrıca, belediyenin kent konseyi kararları üzerinde etkili olacağı düşüncesinin oluşması kent konseyinin rahat çalışamamasına ve dolayısıyla pasif bir kent konseyi yapısının oluşmasına neden olacağı söylenebilir.

Tablo 4.47. Kent Konseyinin Gündem Belirleme Toplantılarına ve Faaliyetlerine Katılım

\begin{tabular}{ll}
\hline $\begin{array}{l}\text { Kent konseyinin gündem belirleme toplantılarına ve } \\
\text { faaliyetlerine katılımınız oluyor mu? }\end{array}$ & Toplam \\
\hline Hiçbir zaman & $0,00 \%$ \\
\hline Bazen oluyor & $40,46 \%$ \\
\hline Sık sık oluyor & $22,90 \%$ \\
\hline Her zaman oluyor & $36,64 \%$ \\
\hline Genel Toplam & $100,00 \%$ \\
\hline
\end{tabular}

Araştırmaya katılan deneklerin, $\% 40,46$ 'sı kent konseyinin gündem belirleme toplantılarına ve faaliyetlerine bazen katıldıklarını, \%22,90'ı sık sık katıldıklarını ve \%36,64 ise her zaman katıldıklarını belirtmişlerdir. Uygulanan anket formunda katılıma etki eden faktörlerle ilgili bir soru sorulmamıştır. Ancak, katılımcıların yaptıkları işlerin mesai oranları, kent konseyini etkileyebilme inançları ve kent konseyinin yapılacak faaliyet ve toplantılar hakkında kendilerinin bilgilendirmemesi gibi faktörlerin etkili olduğu yapılan yüz yüze görüşmelerden anlaşılmıştır.

Tablo 4.48. Kent Konseyinin Genel Kurul Toplantılarına Katılım

\begin{tabular}{ll}
\hline $\begin{array}{l}\text { Daha önce kent konseyi genel kurul toplantılarına } \\
\text { katıldınız mı? }\end{array}$ & Toplam \\
\hline Evet & $97,94 \%$ \\
\hline Hayır & $2,06 \%$ \\
\hline Genel Toplam & $100,00 \%$ \\
\hline
\end{tabular}

Araştırmaya katılan deneklerin, \%97,94'ü daha önce kent konseyi genel kurul toplantılarına katılıklarını, \%2.06'sı ise katılmadıklarını belirtmiştir. Yönetmelik gereği genel kurul toplantıları yılda en az iki kez yapılmaktadır. Çoğunluğun (\%97.94) daha önce genel kurula katılması olumlu bir göstergeyken, \%2,06'lık kesimin katılım göstermemiş olması ise çeşitli sebeplere bağlanabilmektedir, bunlar; kimi kurum temsilcilerinin kent konseyine kurumsal bir etkide bulunacağına inanmaması, katılımı bir zaman kaybı olarak görmesi, üyeliğin gerektirdiği asli vazifenin bilincinde olmaması, iş vb. sebepler gerekçe olarak gösterilebilmektedir.

Tablo 4.49. Kent Konseyine Üyelik Sürecinde Karşılaşılan Engel Durumu

\begin{tabular}{lll}
\hline $\begin{array}{l}\text { Kent konseyine üyelik sürecinde bir engelle } \\
\text { karşılaştınız mı? }\end{array}$ & Toplam \\
\hline Hayır & $85,00 \%$ \\
\hline Evet & $15,00 \%$ \\
\hline (boş) & $0,00 \%$ \\
\hline Genel Toplam & $100,00 \%$ \\
\hline
\end{tabular}


Araştırmaya katılan deneklerin, \%85,00’ kent konseyine üyelik sürecinde bir engelle karşılaşmadıklarını, \%15,00'ı ise bir engelle karşılaştıklarını belirtmiştir. Kent konseyinin teklifi üzerine kurumsal üyelikler yapıldığından \%85'lik oranın bir engelle karşılaşmaması normal görülürken, \%15'lik kesimin karşılaştığı engel nedenlerine bakıldığında yapılan alan araştırmasında ağılıklı olarak karşımıza iki hususun çıktığı görülmüştür; birincisi üyelerle yönetimde yer alan bazı şahıslar arsındaki husumetin üyelik sürecini etkilediği, bir diğeri ise konsey çalışmalarında vermiş olduğu rahatsızlıklardan dolayı yönetim tarafından üyelikten çıkarılan bireylerin tekrardan üyelik için başvurudu bulunduklarında üyeliklerine olumlu cevap verilmediği veya geciktirildiği görülmüştür.

\section{Tablo 4.50. Talep Durumunda Kent Konseyinin Bilgilendirme Durumu}

\begin{tabular}{|c|c|}
\hline $\begin{array}{l}\text { İstediğiniz durumunda kent konseyi, eylem ve } \\
\text { işlemleriyle alakalı tarafınıza bilgilendirme yapıyor } \\
\text { mu? }\end{array}$ & Toplam \\
\hline Hayır & $30,00 \%$ \\
\hline Evet & $70,00 \%$ \\
\hline (boş) & $0,00 \%$ \\
\hline Genel Toplam & $100,00 \%$ \\
\hline
\end{tabular}

Araştırmaya katılan deneklerin, \%70.00'ı kent konseyinin kendilerine bilgilendirilme yaptığını, \%30,00'ı ise kendilerine bilgilendirmenin yapılmadığını belirtmiştir. Yapılan saha çalışmasında katılımcılara bu sorunun devamı niteliğinde sorulan: "Siz daha önce bir istekte bulundunuz mu?" şeklindeki soruya katılımcıların çoğunluğu herhangi bir isteklerinin olmadığını, ancak böyle bir durum söz konusu olduğunda kendilerinin bilgilendirileceğine inandıklarını ifade etmişlerdir.

Tablo 4.51. Kent Konseyi Yönetiminin, Üyeleri Eşit Şekilde Temsili

\begin{tabular}{ll}
\hline $\begin{array}{l}\text { Kent konseyi yönetimi, kent konseyi üyelerini eşit } \\
\text { şekilde temsil ediyor mu? }\end{array}$ & Toplam \\
\hline Hayır & $46,00 \%$ \\
\hline Evet & $54,00 \%$ \\
\hline (boş) & $0,00 \%$ \\
\hline Genel Toplam & $100,00 \%$ \\
\hline
\end{tabular}

Araştırmaya katılan deneklerin, \%54,00’ı kent konseyi yönetiminin kent konseyi üyelerini eşit şekilde temsil ettiğini, \%46,00’ı ise eşit temsil etmediğini belirtmiştir. Üyelerde oluşan temsilde adalet duygusu yönetime olan güveni artıracaktır. Kent konseyi kentin bütün kesimlerinden üyeyi bünyesinde bulundurduğundan, yönetimle muhalefet halinde olanların veya kendilerinin eşit şekilde temsil edildiğine inanmayanların bulunması normal olarak görülmektedir. Ancak dikkat edildiğinde hayır cevabını verenlerin sayısının da azımsanmayacak derecede $(\% 46,00)$ fazla olduğu görülmektedir.

Tablo 4.52. Kent Konseyi Yönetimine Katılım Konusunda Zorluk Yaşanması

\begin{tabular}{ll}
\hline $\begin{array}{l}\text { Kent konseyi yönetimine katılım konusunda zorluk } \\
\text { yaşanıyor mu? }\end{array}$ & Toplam \\
\hline Hayır & $58,00 \%$ \\
\hline Evet & $42,00 \%$ \\
\hline
\end{tabular}




\begin{tabular}{ll}
\hline (boş) & $0,00 \%$ \\
\hline Genel Toplam & $100,00 \%$ \\
\hline
\end{tabular}

Araştırmaya katılan deneklerin, \%58,00'ı kent konseyi yönetimine katılım konusunda zorluk yaşamadıklarını, \%42,00'ı ise zorlukla karşılaştıklarını belirtmiştir. Kent konseylerinin yönetmelik gereği belediyelere bağı olmaları ve bütçelerine belediye tarafından finansman sağlanmaları neticesinde, belediyelerin kent konseyleri yönetimini belirlemede etkili oldukları bilinmektedir. Bu kanıya rağmen anket sonucunun tam tersi çıkması yerel yönetişim açısından olumlu bir gelişme olarak görülmektedir.

Tablo 4.53. Katılımcıların, Kendilerini Kent Konseyinin Paydaşı Olarak Görmesi

\begin{tabular}{ll}
\hline $\begin{array}{l}\text { Kendinizi kent konseyinin paydaşı olarak görüyor } \\
\text { musunuz? }\end{array}$ & Toplam \\
\hline Hayır & $29,50 \%$ \\
\hline Evet & $70,50 \%$ \\
\hline Genel Toplam & $100,00 \%$ \\
\hline
\end{tabular}

Araştırmaya katılan deneklerin, \%70,50'si kendisini kent konseyinin paydaşı olarak gördüğünü, \%29,50'si de kendisini kent konseyinin paydaşı olarak görmediğini belirtmiştir. Kent konseyleri yerel yönetişimin sağlanması için farklı kurumlardan gelen katılımcıları aynı potada eritebildiği sürece başarılı olabileceğinden söz edilebilir. Bu başarının gerçekleşebilmesi için de katılımcıların kent konseyine karşı aidiyet duygusu beslemesi ve kendilerini kent konseyinin paydaşı olarak görmesi gereklidir. Katılımcıların \%70,50 oranıyla böyle bir duyguyu beslemesi, Adana Kent Konseyinin yerel yönetişimi hayata geçirmesi adına olumlu bir göstergedir.

Açık uçlu olarak sorulan "Kent konseyi yönetişim açısından iyi bir model midir?” sorusuna, araştırmaya katılan denekler genel olarak; kent konseyinin eksiklikleri olmasına rağmen geliştirilmesi gereken bir yapı olduğu, mali bağımsızlığı sağlandığı takdirde daha rahat hareket edebileceği ve ayrı bir bütçesinin olması gerektiği konusunda benzer cevaplar vermişlerdir.

Son olarak sorulan "Ekleyeceğiniz herhangi bir soru veya görüş varsa lütfen belirtiniz?" şeklindeki soruya da, dilek ve temenniler şeklinde cevaplar verilmiştir.

\section{SONUÇ}

Kent konseyi üyelerine yapılan anketin katılım profili ele alındığında; erkeklerin sayısı kadınların sayısının yaklaşık iki katıdır ve yaş olarak \%74 oranıyla 46 yaş ve üzeri katılımcı çoğunluktadır. Katılımcıların soy kütüğüne bakıldığında \%73,47 oranının Akdeniz bölgesinde bulunan illerden geldiği ve çoğunluğunun Adanalı olduğu görülmüştür. Mesleki dağılımlarına bakıldığında özel sektör çalışanlarının çoğunlukta olduğu (\%52.04) ve bunları sırasıyla memurların (\%28.57) ve emeklilerin (\%19.39) takip ettiği görülmüştür. Katılımcıların \%7.07' sinin fiziksel bir engelinin olduğu ortaya çıkmıştır. Ayrıca katılımcıların genelinin kent konseyi dışında birden fazla kurum ve kuruluşa üye olduğu görülmüştür. Eğitim durumlarına bakıldığına ise \%42,00'ı lisans, \%20,00'ı yüksek lisans mezunudur ve son olarak çoğunluğunun aylık 4001,00 TL ve üzeri bir gelire sahip olduğu görülmüştür. Ayrıca, 
- Aynı kentte yaşayan insanların kent konseyi yönetimine katılma noktasında duyarlı olmadığı; ancak, kent konseyinin de halka yeterince tanıtılmadığı ortaya çıkmıştır.

- Halkın kent konseyini bilmemesinden dolayı meclis kararlarına katılımı yeterli değildir.

- Kentin hak ve hukukunun korunması ile kentlinin bilinçlendirilmesi yönünde yapılan çalışmalar yetersizdir.

- Üyelerin kent konseyine katılımı ve yönetimi etkileyebilme gücü zayıftır.

- Kent konseyi, karar alma sürecinde bünyesinde bulunan farklı kesimlerin görüşünü alırken, diğer yandan da siyasi düşünce farklılıklarının etkisinde kaldığı ortaya çıkmıştır.

- Kent konseyinin almış olduğu kararlar belediye meclis gündemini etkileyememektedir. Genel itibari ile kent konseyi almış olduğu kararlarda büyükşehir belediyesinin etkisinde kaldığı görülmüştür.

- Kent konseyi yaptığı harcamalarla ilgili üyeleri bilgilendirmediğinden şeffaflık sorununun olduğu ortaya çıkmıştır.

- Kent konseyinin üye yapısı geniş bir temsil platformu özelliği taşımasından dolayı konsey demokratik katılım açısından yeterli görülmüştür.

- Üyeler yerel yönetişimin hayata geçirilmesi noktasında kent konseyini yeterli bulmadıkları; ancak konseyin yönetişimi sağladığına inandıkları ortaya çıkmıştır.

- Kent konseyine üyelik sürecinde bir engelle karşılaşılmadığı ve üyelerin kendilerini kent konseyinin paydaşı olarak gördüğü anlaşılmıştır.

- Hemşehrilik bilincinin geliştirilmesine yönelik kent konseyinin çaba sarf ettiği ancak bunun istenilen seviyede olmadığı görülmüştür

- Adana kent konseyi meclis toplantılarına ve bu meclislerin gerçekleştirdiği faaliyetlere genel itibariyle istenilen seviyede katılım gerçekleşmezken, halkın ilgisini çeken konularda katılımın arttığı görülmüştür.

- Konseyin yerel yönetişimi hayata geçirme adına yönetişimin ayaklarını oluşturan kamuözel sektör ve STK üçgeninde ilgili çalışmaları ele alındığında, ağılıklı olarak kadınlar, engelliler ve gençlere yönelik çalışmaların yürütüldüğü, ortak olarak da en çok sivil toplum kuruluşları ve Adana Büyükşehir Belediyesiyle faaliyetler gerçekleştirdiği ortaya çıkmıştır; ancak ortaklık noktasında yönetişimin bir ayağını oluşturan kamu kurumlarının yeterli seviyede yer almadığı görülmüştür.

- Yapılan alan araştırmasında üyelerin birbirine yakın sorulara farklı cevaplar verdiği ve kent konseyini tam olarak bilmedikleri ortaya çıkmıştır. Örneğin bir taraftan halkın kent konseyine katılım noktasında duyarsız olunduğu söylenirken, diğer taraftan da halkın kent konseyi yönetimine katılma noktasında taleplerinin olduğu söylenmiştir.

- Kent konseyleri sadece seçimden seçime oy kullanan vatandaş profilinin önüne geçmek ve aktif yurttaşlığı artırmayı amaçlayan kurumlardır. Adana Kent Konseyinin aktif yurttaşığın hayata geçirilmesi noktasında çok pasif kaldığı yapılmış faaliyetlerden anlaşılmıştır. Yapılan faaliyetler daha çok mağdur ve eksik grupların ihtiyaçlarının giderilmesi şeklinde gerçekleştirilmiştir. Önemli olan ise karar alma süreçlerinin her aşamasına katılma isteği duyan bilinçli bireylerin sayısının artırılması ve bu kapsamda farkındalık oluşturarak konuyla alakalı çalışmaların hayata geçirilmesidir. 
- Kuruluşundan bu yana çalışmalarında özellikle kent içi ulaşım, imar, kentsel dönüşüm gibi teknik konulara ağırlık vermesi ile kent konseyi halk tarafından teknokrat bir yapı olarak algılanmıştır. Bütçe konusunda belediyeye bağlı olması dolayısıyla birçok çalışmayı belediye ile işbirliği içerisinde yapması belediye birimi gibi algılanmasına neden olmuştur.

\section{KAYNAKÇA}

AYDIN, Ahmet Hamdi, (2016), Kamu Yönetimine Giriş, Seçkin Yayınları, Ankara, 3. Baskı.

BALCl, Asım, (2005), "Türkiye-AB ilişskileri Perspektifinden Kamu Yönetimi Sisteminin Yeniden Yapılandırılması", Amme İdaresi Dergisi, 38(4), ss. 23-37.

BAYRAMOĞLU, Sonay, (2005), Yönetişim Zihniyeti Türkiye'de Üst Kurullar ve Siyasal İktidarın Dönüşümü, İletişim yayınları, İstanbul.

2002. "Küreselleşmenin Yeni Siyasal iktidar Modeli: Yönetişim", Praksis 7, Yaz Sayısı, Ankara. ss. 85-116.

BAYRAM, Nuran, (2009), Sosyal Bilimlerde SPSS ile Very Analizi, Ezgi yayınları, İstanbul, ikinci Baskı.

BELLi, Aziz, (2016), "Türkiye'de Kent Konseylerinin Iş̧levselliği Önündeki Sorunlar ve Çözüm Önerileri: Büyükşehir Belediyeleri Örneği", Yayımlanmamış Doktora Tezi, Kahramanmaraş Sütçü İmam Üniversitesi, Sosyal Bilimler Enstitüsü, Kahramanmaraş.

BÜLBÜL, Zübeyr, (2009), “Ekonomik Dönüşüm Süreci, Kentleşme, Sürdürülebilir Kalkınma ve Kent Konseyi", Yayımlanmamış Yüksek Lisan Tezi, Marmara Üniversitesi Sosyal Bilimler Enstitüsü, İstanbul.

COSKUN, Recai, (2006), "lyi Yönetişim Her Derde Deva Mı?", Yerel Siyaset Dergisi, 1(6), ss. $42-44$

ÇUKURÇAYIR, Mehmet Akif, (2003), Yurttaş Odaklı Yerel Yönetim, Çizgi Yayınları, İstanbul.

, (2005), Siyasal Katılım Olanakları Açısından Yerel Siyaset: Yönetişim ve Yerel Alanda Yararlanılabilecek Diğer Yöntemler, Nobel Yayıncılık, Ankara.

(2009), Yurttaş Odaklı Yerel Yönetim, Çizgi Kitabevi, Konya.

DPT, (2007), Kamuda İyi Yönetişim, Dokuzuncu Kalkınma Planı, Özel ihtisas Komisyonu Raporu, Ankara.

EROĞLU, H. Tuğba., (2010), "Sürdürülebilir Yerel Kalkınma ve Kent Konseyleri", Dumlupınar Üniversitesi Sosyal Bilimler Dergisi, Nisan, (26), ss. 44-55.

GÜMÜŞ, Fatih, (2009), "Yönetişim Kavramına Eleştirel Bir Yaklaşım ve Tuzla Kent Konseyi Örneği", Yayımlanmamış Yüksek Lisans Tezi, Haliç Üniversitesi, Sosyal Bilimler Enstitüsü, İşletme Ana Bilim Dalı, İstanbul.

GÜNDOĞAN, Ertuğrul, (2010), "Kavram, Kuram ve Boyutlar", (Ed. M. Akif Çukurçayır, H. Tuğba Eroğlu, Hülya Eşki Uğuz), Yönetişim: Kuram-Boyutlar-Uygulama, Çizgi Kitabevi, Konya.

IULA-EMME, (2002), Sürdürülebilir Kalkınma ve Yönetişim: Birleşmiş Milletler Sürdürülebilir Kalkınma Dünya Zirvesi Türkiye Ulusal Raporu TEMA III, İstanbul: IULA-EMME, ss. 17-20. 
KAYA, Erol, (2007), "Belediyelerde Toplam Kalite Yönetimi", (Ed. Erol Kaya, Hulusi Şentürk, Osman Danış, Sami Şimşek), Modern Kent Yönetimi- I, Okutan Yayıncılık, İstanbul.

ÖZCAN, Lütfi, YURTTAŞ, Fatma, (2010), “Kent Konseyleri Müzakereci Demokrasinin Uygulama Alanı Olarak Düşünülebilir mi?”, (Ed. Bekir Parlak), Yerel Yönetimler, Yerel Siyaset ve Kentsel Politikalar, Dora Yayıncılık.

SAĞIR, Meral, (2003). "Küreselleşme Süreci ve Siyasal Katılımda Yeni Arayışlar: Yerel Gündem 21 Antalya. Kent Konseyi Kadın Meclisi", Çağdaş Yerel Yönetimler Dergisi, 12(4), ss. 28-41.

http://www.adana.gov.tr/sosyal-durum (Erişim Tarihi: 15.06.2016)

http://www.adanakentkonseyi.org.tr/belediyemiz-TARIH-Ccedil-E, (Erişim Tarihi: 05.05.2016) 